\title{
Alteration of freshwater ecosystem services under global change - A review focusing on the Po River basin (Italy) and the Red River basin (Vietnam)
}

\author{
Hung Vuong Pham ${ }^{\mathrm{a}, \mathrm{b}}$, Silvia Torresan ${ }^{\mathrm{a}, \mathrm{b}}$, Andrea Critto ${ }^{\mathrm{a}, \mathrm{b}}$, Antonio Marcomini ${ }^{\mathrm{a}, \mathrm{b}, *}$ \\ a Fondazione Centro Euro-Mediterraneo sui Cambiamenti Climatici (CMCC), via Augusto Imperatore 16, 73100 Lecce, Italy \\ b Department of Environmental Sciences, Informatics and Statistics, University Ca' Foscari Venice, Via Torino 155, 30172 Venezia-Mestre, Venice, Italy
}

\section{H I G H L I G H T S}

- We assessed the impacts of climate change and human activities on freshwater services.

- Indicators and a conceptual framework of climatic/non-climatic effects are analyzed.

- The literature focuses more on the provisioning and regulating services.

- Consistent terminologies and classifications are needed for future risk assessments.

\section{A R T I C L E I N F O}

\section{Article history:}

Received 22 May 2018

Received in revised form 5 October 2018

Accepted 22 October 2018

Available online 24 October 2018

\section{Keywords:}

Climate change

Human activities

Ecosystem services framework

Risk assessment

\section{GR A P H I C A L A B S T R A C T}

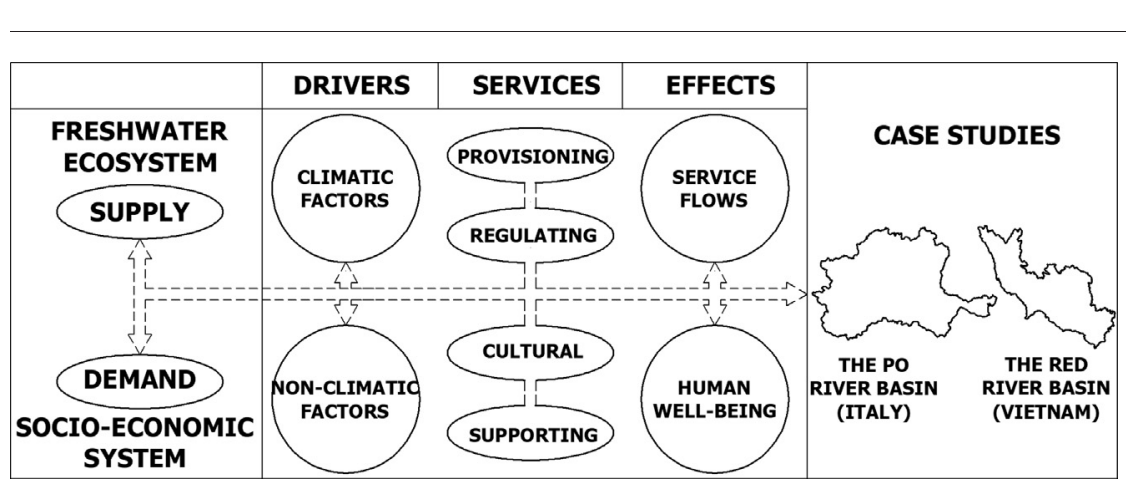

\section{A B S T R A C T}

Freshwater ecosystem services are negatively affected by factors such as climate change (e.g. changes in temperature, precipitation, and sea level rise) and human interventions (e.g. agriculture practices, impoundment of dams, and land use/land cover change). Moreover, the potential synergic impacts of these factors on ecosystems are unevenly distributed, depending on geographical, climatic and socio-economic conditions. The paper aims to review the complex effects of climatic and non-climatic drivers on the supply and demand of freshwater ecosystem services. Based on the literature, we proposed a conceptual framework and a set of indicators for assessing the above-mentioned impacts due to global change, i.e. climate change and human activities. Then, we checked their applicability to the provisioning services of two well-known case studies, namely the Po River basin (Italy) and the Red River basin (Vietnam).

To define the framework and the indicators, we selected the most relevant papers and reports; identified the major drivers and the most relevant services; and finally summarized the fundamental effects of these drivers on those services. We concluded that the proposed framework was applicable to the analyzed case studies, but it was not straightforward to consider all the indicators since ecosystem services were not explicitly considered as key assessment endpoints in these areas. Additionally, the supply of ecosystem services was found to draw much more attention than their demand. Finally, we highlighted the importance of defining a common and consistent terminology and classification of drivers, services, and effects to reduce mismatches among ecosystem services when conducting a risk assessment.

C 2018 Published by Elsevier B.V.

\footnotetext{
* Corresponding author at: Fondazione Centro Euro-Mediterraneo sui Cambiamenti Climatici (CMCC), via Augusto Imperatore 16, 73100 Lecce, Italy. E-mail address: marcom@unive.it (A. Marcomini).
} 


\section{Introductory review}

Freshwater accounts for only $0.01 \%$ of water volume in the world and about $0.8 \%$ of the land surface, but this small amount of water is supporting at least 100,000 species (Cazzolla Gatti, 2016). There are about 263 international rivers, which occupy $45 \%$ of the land surface area of the Earth, supporting $>40 \%$ of the global human population (Cazzolla Gatti, 2016). Freshwater provides a wide range of ecosystem services (ES) such as provisioning services (e.g. water for agriculture), regulating services (e.g. buffering of flood flows), cultural services (e.g. river viewing) and supporting services (role in nutrient cycling) (Aylward et al., 2005).

Unfortunately, climate change (CC) has altered freshwater ecosystems on both supply side and demand side due to changing temperatures, precipitations, and water flow regimes (Carpenter et al., 2011; Däll and Zhang, 2010). These changes would cause more severe floods, droughts, and sea level rise (SLR) in the future respect to the reference period (1980-1999), under the climate change scenarios A2 (high $\mathrm{CO}_{2}$ emission) and B2 (medium $\mathrm{CO}_{2}$ emission) (Giang et al., 2013). In regard to $\mathrm{CC}$, the concentrations of greenhouse gases such as carbon dioxide $\left(\mathrm{CO}_{2}\right)$, methane $\left(\mathrm{CH}_{4}\right)$ and nitrous oxide $\left(\mathrm{N}_{2} \mathrm{O}\right)$ have shown large increases since 1750 (40\%, 150\%, and 20\%, respectively) (IPCC, 2014). These changes led to an increase in average temperature of 0.85 (0.65-1.06) ${ }^{\circ} \mathrm{C}$ over the period 1880 to 2012 , a rise in global mean sea level of $0.19 \mathrm{~m}(0.17-0.21) \mathrm{m}$ over the period (1901-2010). Consequently, these anomalies had changed the availability of freshwater (Colombani et al., 2016a), shifted river discharge (Suen, 2010), and intensified the magnitude and frequency of extreme events such as heavy rainfalls (Coppola et al., 2014; Madsen et al., 2014; Sorg et al., 2012; Trenberth, 2011), floods, and droughts (Kundzewicz et al., 2008). For instance, the IPCC (2014) projected that the annual runoff would decrease in the Southern Europe of $6-36 \%$ by 2070 s and the low flow in summer may decrease up to $80 \%$ in some rivers in southern Europe. Yet, the timing of the maximum monthly river discharge would be shifted by at least one month on one-third of the global land area.

Additionally, since temperature and precipitation patterns affect the rates of nutrient cycling and toxin breakdown, and thermal niches of organisms, CC could further affect the quality of freshwater (Carpenter et al., 2011), and aquatic species (Däll and Zhang, 2010). For instance, a higher temperature could increase the rate of uptake of pollutants by changing ventilation rate, increasing metabolic rate and decreasing oxygen solubility, which could lead to eutrophication (Schiedek et al., 2007). The decrease in river discharges could reduce the genetic flow and variation of aquatic biota population due to stream fragmentation. Moreover, precipitation patterns could modify sediment flow and the erosivity rate, which could further modify the freshwater quality. Specifically, heavy rainfall and high flows could increase loads of suspended solids, sediment yields, and contaminant metal fluxes because of soil erosion and sediment transport from the land surface. In contrast, droughts could exacerbate acidification by lowering water tables, creating aerobic conditions and enhancing oxidation of sulfur to sulfate (Whitehead et al., 2009).

Furthermore, different effects of CC (e.g. temperature anomalies, precipitation anomalies and SLR) not only affect individually FreshWater Ecosystems Services (FWES), but they may also interact with each other quite differently (Woodward et al., 2010). As a result, CC would have impacts on water provision, transportation, hydropower production, flood regulation, natural filtration, and water treatment (Kernan et al., 2011; Moore et al., 1997; Woodward et al., 2010).

Beside CC, freshwater ecosystems are threatened by many anthropogenic stressors such as overfishing, water pollution, flow regimentation, degradation of habitats, invasion of exotic species transported either intentionally or accidentally by human-mediated vectors, and hydroelectric power stations (Cazzolla Gatti, 2016; Däll and Zhang, 2010). In addition, deforestation, poor land use management and manufacturing practices are destroying carbon sinks, imposing more stress on
FWES (Tobergte and Curtis, 2013). On the one side, requiring higher demand of freshwater, the upward trend of population and urbanization could modify the availability and distribution of freshwater. For instance, anthropogenic water consumption resulted in a decrease in mean annual runoff by $5 \%$ or more in many river basins, e.g. the heavily irrigated areas at middle latitudes in Asia and the western part of the United States, during the examined period (1971-2000) (Haddeland et al., 2014).

On the other side, these anthropogenic stressors could affect the quality of freshwater. For instance, chemicals and pollutants associated with human activities (i.e. agriculture practices, industrial areas and urban traffic) were recognized as relevant threats of freshwater quality (Ahmad et al., 2016; McCoy et al., 2015). Specifically, agricultural practices were considered as major non-point sources of macronutrient and pesticides transported to water bodies by rainfall and water runoff. When applied to crops, pesticides intercepted by the soil surface undergo partitioning between the soil, water and air. A proportion of pesticides may leave the soil/water system by volatilization to the atmosphere. Some pesticides remain in the soil partition between soil and rainfall water. The ratio of the concentration in the soil to the concentration in the water is called the soil sorption coefficient. It is an equilibrium between pesticide concentration divided between soil and water. For pesticides highly absorbed by soil particles, erosion and mechanical runoff are the main processes of transport to water bodies (Bloomfield et al., 2006).

Additionally, humans directly influence the dynamics of the water cycle and river flow regimes through dams construction for water storage, and through water withdrawals for industrial, agricultural, or domestic purposes. In particular, the presence of over 45,000 dams exceeding $15 \mathrm{~m}$ height in the world would have influences on biodiversity and ecological function of river systems as well as disrupting sediment flux, thermal regimes, and the fertile soils of the flood basins (Mooney et al., 2009). For instance, Haddeland et al. (2014) found out that the impacts of human disturbances (i.e. impoundment and operation of dams and water consumption) on annual runoff in some river basins are greater than the impacts of expected CC over the next 40 years. Similarly, in some irrigated areas in Asia and the western United States, the effects of current anthropogenic interventions on mean annual runoff are stronger than those driven by the increased temperature of a 2 or $3{ }^{\circ} \mathrm{C}$ (Haddeland et al., 2014).

Indeed, the effects of CC on ES vary in time and space and are rarely homogeneous (Barker et al., 2010). For instance, while an increase in precipitation was observed since 1901 over land north of $30^{\circ} \mathrm{N}$, a decrease in precipitation over land between $10^{\circ} \mathrm{S}$ and $30^{\circ} \mathrm{N}$ was detected after the 1970s (Carpenter et al., 2011). In the end, together with increasing pollution, overpopulation and human activities, climate change could lead to the deterioration and depletion of available water sources, with negative consequences on water security.

Therefore, it is noteworthy that the impacts of climatic and nonclimatic factors on FWES result from different combinations of climatic, geographical and socio-economic conditions. Thereafter, we choose the two well-known case studies, namely the Po River basin (PRB) in Italy and the Vietnamese part of the Red River basin (hereafter it refers to the Red River basin or RRB), to investigate the above-mentioned aspects. Although they are located in two different continents, they have some relevant common characteristics. Firstly, they are both transnational basins. While the PRB is shared among Italy, Switzerland and France, the RRB is shared among Vietnam, China and Laos. Besides, they have a similar size (i.e. $74,000 \mathrm{~km}^{2}$ and $86,700 \mathrm{~km}^{2}$, respectively). Secondly, they are important to the national economy, contributing to the gross domestic product (GDP) about $40 \%$ and $20 \%$, respectively. Thirdly, freshwater is intensively consumed by several conflicting water uses, such as agriculture, environment protection (e.g. the water demand for maintaining the minimum environmental flow) and hydropower generation. Finally, FWES on these case studies are negatively affected both by climatic factors and non-climatic factors. 
Noticeably, most of the CC impact assessment studies on FWES developed in recent years have focused on the impacts of temperature anomalies (Haddeland et al., 2014). Others consider the changes in mean precipitation and in river flow regimes, including long-term average flows, low flows and high flows (Däll and Zhang, 2010), and SLR (Carpenter et al., 2011). Thus, this review focuses on these relevant climate factors, namely temperature anomaly, precipitation anomaly and SLR. Meanwhile, anthropogenic factors, which vary locally and regionally from one case study to the other, will be further discussed in each case study, i.e. agriculture activities in the PRB and the impoundment and operation of cascade reservoirs and dams in the RRB.

In this context, the objectives of this paper are the following:

- Propose a conceptual framework and a set of indicators to assess the impacts of climatic/non-climatic factors on FWES, considering both the supply and the demand side of such services (Sections 2.1 and 2.2);

- Check the feasibility of the framework and indicators for the two selected river basins, namely the Po River basin in Italy and the Vietnamese part of the Red River basin, which are highly affected by several global change drivers and featured by different geographical, climatic and socio-economic conditions (Section 3);

- Highlight some gaps in the literature and recommend further research directions to bridge these gaps, especially with the reference to the selected case studies (Section 4).

\section{Methods and materials}

The literature-based review started with a search of scientific papers in the field of "ecosystem services". To find the publications related to FWES, we used the following keywords, either alone or in combination: "ecosystem service", "ecosystem services", "ecosystem function”, “ecosystem process", "ecosystem benefit", and "freshwater". To find the publications related to the selected case studies, namely the Po River (Italy) and the Red River (Vietnam), we used additional keywords: "Po river basin", "Po river delta", "Po river valley", "Red river basin", and "Red river delta".

Then, for each publication, we identified the main drivers of changes and classified them into two groups, i.e. the climatic drivers (temperature, precipitation, rainfall, etc.) and the non-climatic drivers (land use change, population dynamics, dams construction, etc.). At the same time, all the categories of FWES were classified following the classification of the Millennium Ecosystem Assessment (Aylward et al., 2005). Finally, we summarized the effects of the aforementioned drivers on each category of FEWS using the conceptual framework (Section 2.1 and Fig. 1) and a set of indicators (Section 2.2 and Table 1). Subsequently, we checked the feasibility of this conceptual schematization and the proposed indicators by applying them to assess the impacts of global change on FWES in the selected case studies, namely the PRB (Section 2.3.1) and the RRB (Section 2.3.2). The results are extensively described in Section 3.

\subsection{Conceptual framework to assess the impacts of global change on FWES}

The conceptual framework draws the main components of the freshwater ecosystem and the socio-economic system, the main interactions between them and the relevant processes affecting both the supply and demand of FWES (Fig. 1). In the vertical axis of this figure, the freshwater ecosystem is represented by the part A while the socio-economic system is represented by the part B. In the horizontal axis, all the drivers of change are listed in the block I with the climatic factors on the left and non-climatic factors on the right. Then, all the FWES are reported in block II, classified into four categories, namely provisioning, regulating, cultural and supporting services. Finally, the effects of all drivers on the FWES services are reported in block III.

\subsubsection{Drivers of changes}

Drivers of changes are the main natural and anthropogenic forces, which can determine variations in the state of the environment and/or human system. These drivers cause certain pressures on freshwater resources which result in impacts on FWES, either by changing the quantity and/or by changing the quality of freshwater. Thus, it is important to identify the main drivers and to classify them in suitable categories (e.g. climatic and non-climatic drivers). In this conceptual framework, the main climatic drivers are temperature, precipitation, rainfall pattern, extreme events, land cover changes and SLR. These drivers interact with the natural system through natural processes including photosynthesis, pollination, decomposition, and others. On the other side, the main non-climatic drivers are land use changes, population dynamic, dams construction, urbanization and agriculture practices.

\subsubsection{Freshwater ecosystem services}

FWES are the benefits people obtain from freshwater ecosystems, including provisioning, regulating, cultural, and supporting services (Aylward et al., 2005). First, freshwater is a provisioning service as it refers to the human use of fresh water for domestic, agriculture and industrial use, power generation, and transportation. Additionally, the hydrological cycle also sustains inland water ecosystems, including rivers, lakes, and wetlands. Therefore, important regulating FWES include water regulation (i.e. hydrological flow), water purification and waste treatment, erosion regulation and water-related natural hazard regulation. Then, freshwater ecosystem also provides the cultural services such as the human benefits associated with river rafting, kayaking, hiking, fishing as a sport, and river viewing. Finally, freshwater contributes to other supporting services such as primary production, predator/prey relationships and ecosystem resilience.

\subsubsection{Effects of global change on FWES}

Effects of global change on FWES are the changes in the physical, chemical or biological state of the freshwater system, determining the quality of ecosystem services and the welfare of human beings. The drivers of changes affect the FWES not only on the supply side through specific ecosystem functions ${ }^{1}$ (e.g. producing biomass, decomposing organic matters, and dispersing plant seeds), but also on the demand side, through direct/non-direct uses of freshwater. For instance, extreme rainfall events can lead to hydrogeological hazards such as inundation, flood and landslides, affecting agriculture, transportation and communication infrastructure. In addition, the water demand in this period may increase due to the needs of the population for sanitary purposes.

\subsubsection{Interaction between freshwater ecosystem and socio-economic system}

It can be seen clearly from Fig. 1 that the supply of and the demand for ES are separated. While the supply is provided by freshwater ecosystems, the demand is required by socio-economic systems. Nevertheless, this separation is not completely sharp since the systems share some common parts such as drivers of changes, services and effects. For instance, temperature, as a climatic driver, affects the water cycle (and supply) by changing water vapor concentrations, clouds, precipitation patterns, and streamflow patterns. Similarly, temperature changes affect the socio-economic system by altering the water consumption and demand rates.

Regarding the services, lakes and rivers supply the recreational services such as rafting, kayaking, hiking, fishing and river watching. Additionally, they also provide maintenance services such as the regulation of flow and level during the dry season. These services are driven by both climatic and non-climatic factors. Noticeably, the climatic drivers are usually driven by the natural system (e.g. circulation of water in the ocean, weather and climate, and water drainage) while the non-

\footnotetext{
${ }^{1}$ Ecosystem functions are the biological, geochemical and physical processes and components that take place or occur within an ecosystem.
} 

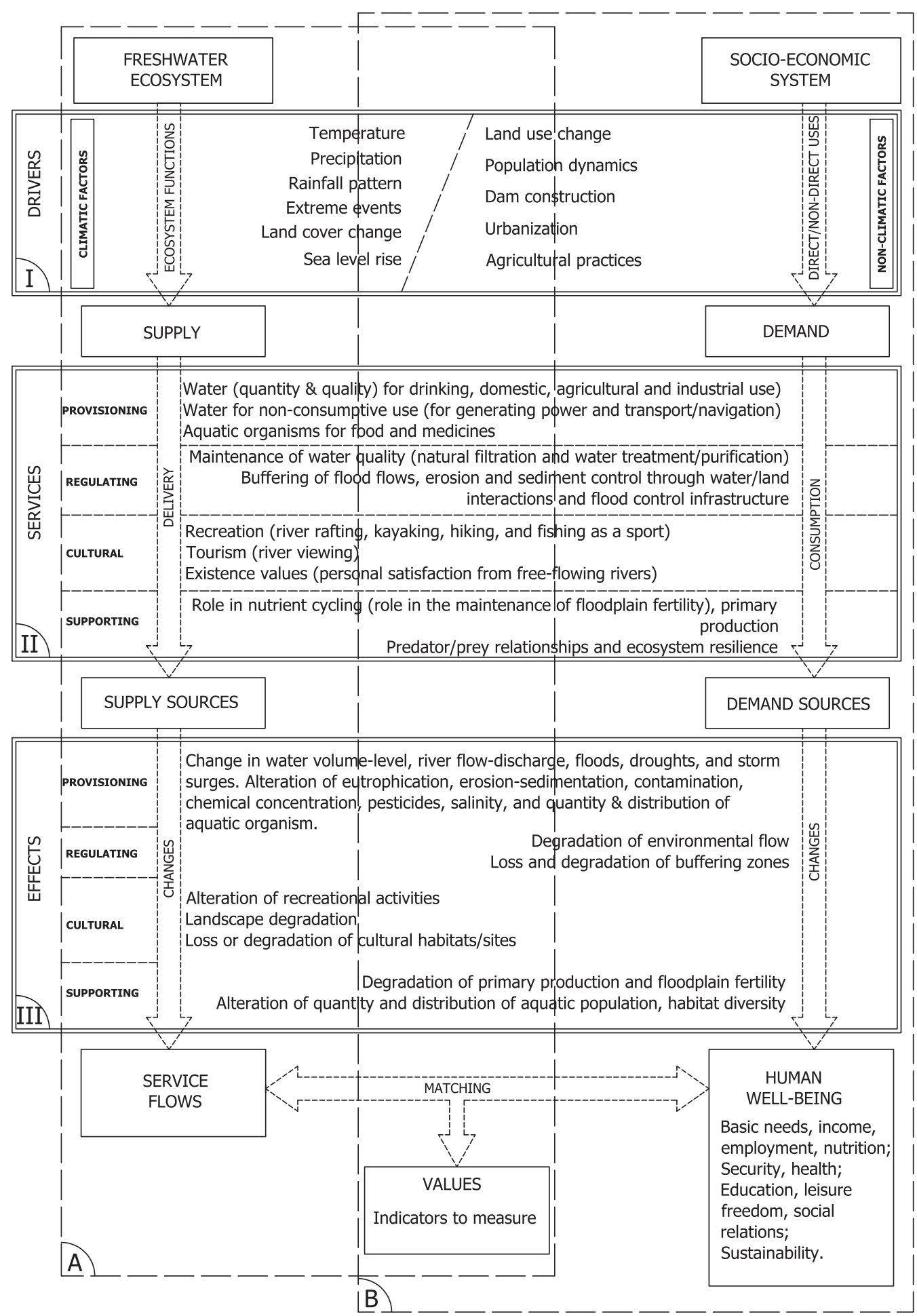

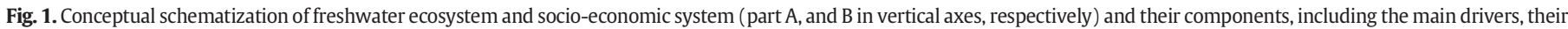
services, and the effects of these drivers on FWES (block I, II, and III in horizontal axes, respectively).

Source: adapted from Aylward et al. (2005); Wolff et al. (2015).

climatic drivers are often governed by the socio-economic system (e.g. human settlements, transportation routes, communication systems, and economics). However, the climatic and non-climatic drivers interact with each other and, consequently, intensify the impacts on FWES. On the one side, climate drivers (e.g. temperature and precipitation) are expected to alter the hydrological cycle, resulting in further changes in the supply of food, water and energy. On the other side, non-climatic factors (e.g. land use and urban expansion) may affect climatic factors by changing infiltration and evapotranspiration rates (Sample et al., 2016).

Consequently, the climate and non-climate drivers modify service's flows on the supply side and the demand side through the delivery (e.g. from lakes and rivers to irrigation networks) and the consumption of freshwater (e.g. domestic, irrigation, and energy), respectively. Noticeably, on the one side, freshwater ecosystem can provide supplies in a specific location at a given time regardless of the demand from 
H.V. Pham et al. / Science of the Total Environment 652 (2019) 1347-1365

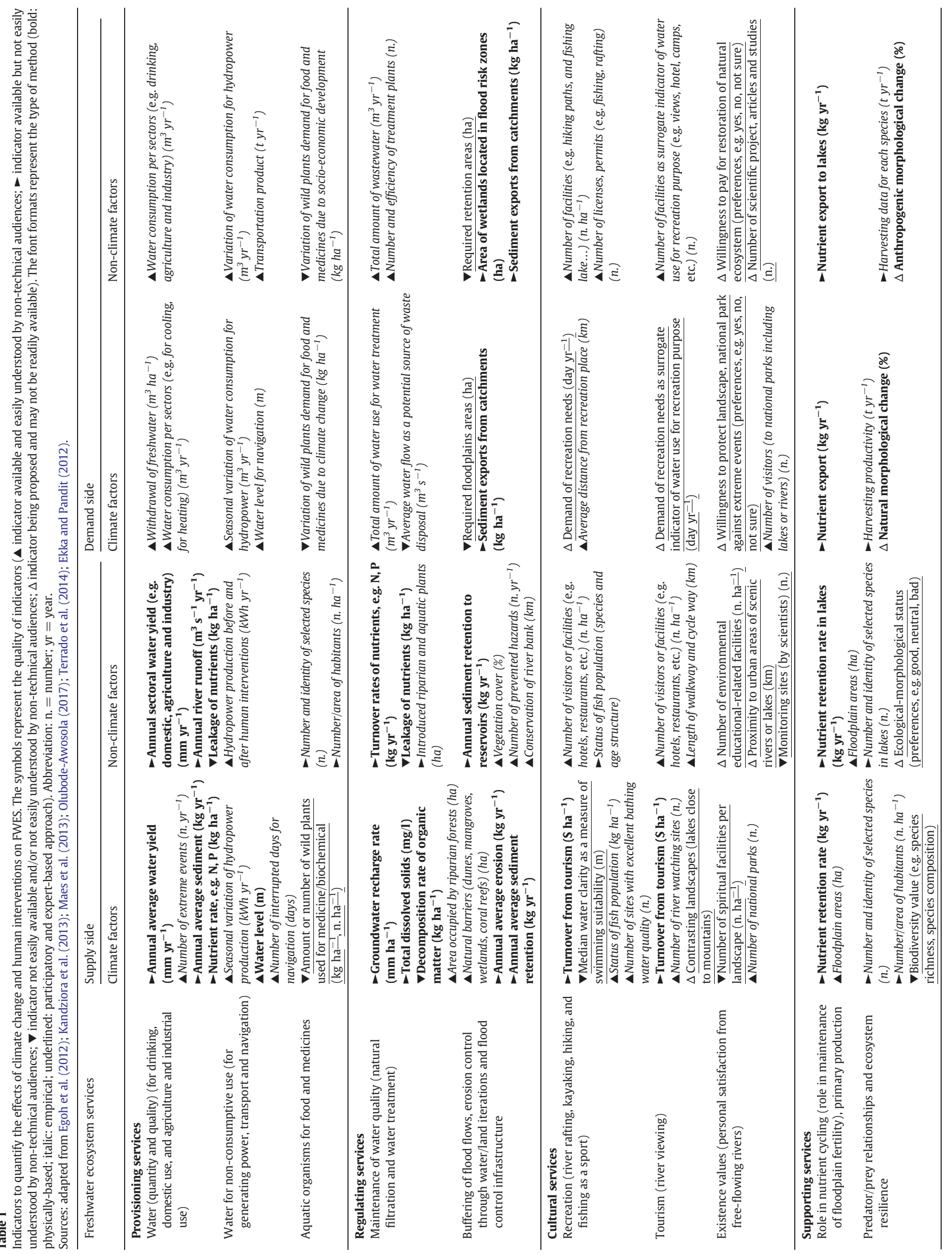


the socio-economic system. On the other side, demands from socioeconomic system are independent from the supplies provided by freshwater ecosystem. Therefore, the basic needs of human well-being (e.g. income, employment, nutrition, security, health, education, leisure, freedom, etc.) would be achieved if the supplies are maintained over time and the demands are adapted to ensure no net loss of biodiversity and ecosystem services (European Commission, 2011). Nevertheless, the supplies and demands vary in time and in space depending on geographical, climatic and non-climatic conditions. Thus, we propose a list of indicators (Table 1) to quantify, map, assess, and compare the changes in supply and demand of FWES under climate change and human interventions.

\subsection{Indicators to quantify the effects of global change on FWES}

There is a wide range of indicators to assess the impacts of global changes on FWES and, specifically, FWES. Nevertheless, they are not consistent and well-distributed among the four categories of FWES (i.e. provisioning, regulating, cultural and supporting services), depending on authors, fields of study and purpose of research. In fact, one indicator can be used for more than one type of FWES (e.g. annual average water yield can be used to assess the impacts of both climatic factors and non-climatic factors on provisioning services). Moreover, as shown in Table 1, most of the FWES categories can be associated with more than one indicator to quantify, assess or map their services.

Among FWES, provisioning services are the most commonly reported in the literature, followed by regulatory services and cultural services. Supporting services are the least common because they usually overlap with other service categories or it is not straightforward to differentiate them. For instance, pollination service can be considered as either the regulating service (i.e. it is an agriculture input that ensures the production of crops) or the supporting service (i.e. a necessary service for the production of other services such as the provisioning of food) (Kandziora et al., 2013). Therefore, the number of indicators for this category is much lower than those for other categories.

Furthermore, the selection of indicators depends on the purpose of a study, the applied methodological approach and the data availability (Olubode-Awosola, 2017; Wolff et al., 2015). Thus, it is noteworthy to study not only the number of indicators but also the quality of indicators and the methods to obtain them.

Regarding the quality of indicators, they can be classified into four categories, namely (i) indicator available and easily understood by non-technical audiences; (ii) indicator available but not easily understood by non-technical audiences; (iii) indicator not easily available and/or not easily understood by non-technical audiences; and (iv) indicator being proposed and may not be readily available (OlubodeAwosola, 2017). The quality of each indicator in Table 1 is represented by a symbol marked before it and by the legend in the caption of this table. It can be seen clearly from Table 1 that the majority of indicators is available and understandable without or with a little technical explanation. For instance, water level and water consumption per sector can be easily understood by readers while annual average water yield and annual river runoff can be understood by non-technical audiences when the definitions of water yield and runoff are given. Interestingly, the cultural services and the supporting services have many indicators which are proposed but may not be readily available. For example, it might be difficult to find suitable indicators for some generic services like life cycle maintenance and maintenance of genetic diversity (Egoh et al., 2012).

Regarding the methods to obtain these indicators, they can be classified into three categories, namely (i) physically based; (ii) empirical; and (iii) participatory or expert-based (Wolff et al., 2015). Physically based methods are suitable for the scale on which relevant physical processes occur, such as the river basin scale for hydrological processes. Empirical methods work better with larger scale case studies with less detailed data requirements. Participatory approaches are most suitable for small-scale researches. These approaches consider the preferences of the participants such as stakeholders, experts and administrators. Therefore, the choice of the method depends on the scale of the case study and the data availability. In Table 1, the method used to quantify each indicator is represented by the format of the text and by the legend in the caption of this table. Noticeably, since one indicator can be obtained by more than one method, the classification of an indicator was performed based on the popularity of these methods. It can be seen from Table 1 that the empirical methods are the most popular method across all FWES because these methods are suitable for a wide range of studies and they require less detailed data. The physically based methods are widely applied for provisioning services and regulating services, while the participatory and expert-based approaches are more popular in the cultural services.

Finally, it is important to point out that the use of these indicators does not necessarily allow the comparison among services (e.g. one service is more valuable than the others) because of the differences in metrics and methods. These indicators provide useful information for trade-off analysis, enabling markets for ES, supporting the establishment of environmental regulations and payments for ES (Olubode-Awosola, 2017).

\subsection{Case studies}

\subsubsection{The Po River basin}

The Po River is the longest Italian river (i.e. about $652 \mathrm{~km}$ long). Its basin (i.e. about $74,000 \mathrm{~km}^{2}$ ) is a crucial resource for the Italian economy, accounting for about $40 \%, 35 \%$, and $37 \%$ of the gross domestic product, agricultural product, and industrial product, respectively. It has 141 main tributaries which have a total length of about $6750 \mathrm{~km}$ and $31,000 \mathrm{~km}$ for the natural and artificial channels, respectively. About 450 lakes are located in the Po River watershed (Montanari, 2012) (Fig. 2).

Freshwater of the Po River is intensely used for irrigation, hydropower production, and domestic purposes (Coppola et al., 2014). The average volume of annual precipitation is about $78 \mathrm{~km}^{3}$, in which $47 \mathrm{~km}^{3}(60 \%)$ is converted in outflow volume at the closure section, $20-25 \mathrm{~km}^{3}$ is accounted for evapotranspiration, $17 \mathrm{~km}^{3}$ is supplied for irrigation, $5 \mathrm{~km}^{3}$ is supplied for civil and industrial users, and the rest is charged into groundwater. The mean daily discharge at Pontelagoscuro terminal station is $1470 \mathrm{~m}^{3} \mathrm{~s}^{-1}$. The monthly distribution of rainfall is typically minimum in February and July, in both the lowlands and in the mountain areas, and maximum in late spring (May-June) and in the middle of autumn (November) (Baruffi et al., 2012).

Recently, this river basin has drawn huge attention from scientists and authorities on assessing the availability and distribution of freshwater resources in term of water quantity and water quality. Specifically, the extreme events (i.e. intensive rainfalls, floods and droughts) and their related impacts have been well reported (Coppola et al., 2014; Domeneghetti et al., 2015; Masoero et al., 2013; Montanari, 2012; Ravazzani et al., 2014). Other studies focused on the problems related to water quality, i.e. pollutants and eutrophication (Castaldelli et al., 2013; Colombani et al., 2016a; Corazzari et al., 2015; Facca et al., 2014; Luigi et al., 2015; Tesi et al., 2013).

\subsubsection{The Red River basin}

The RRB is a transnational basin covering an area of $169,000 \mathrm{~km}^{2}$ between Vietnam (51.3\%), China (48\%), and Laos (0.7\%). The three main tributaries of the Red River ( $\mathrm{Da}$, Lo, and Thao) rise in the northern part of the basin and join before reaching the large floodplain in the delta region, which extends over $21,000 \mathrm{~km}^{2}$ (Giuliani et al., 2016). Due to the limitation of data availability and accessibility, this review focuses only on the Vietnamese part of the river. Out of the three main tributaries, the Da River is the most important water source, contributing $42 \%$ to the total discharge at Son Tay (Castelletti et al., 2012). Additionally, the Red River Delta (RRD) is an important part of the RRB, accounting for approximately $23 \%$ of the population and $56 \%$ of rice products in 


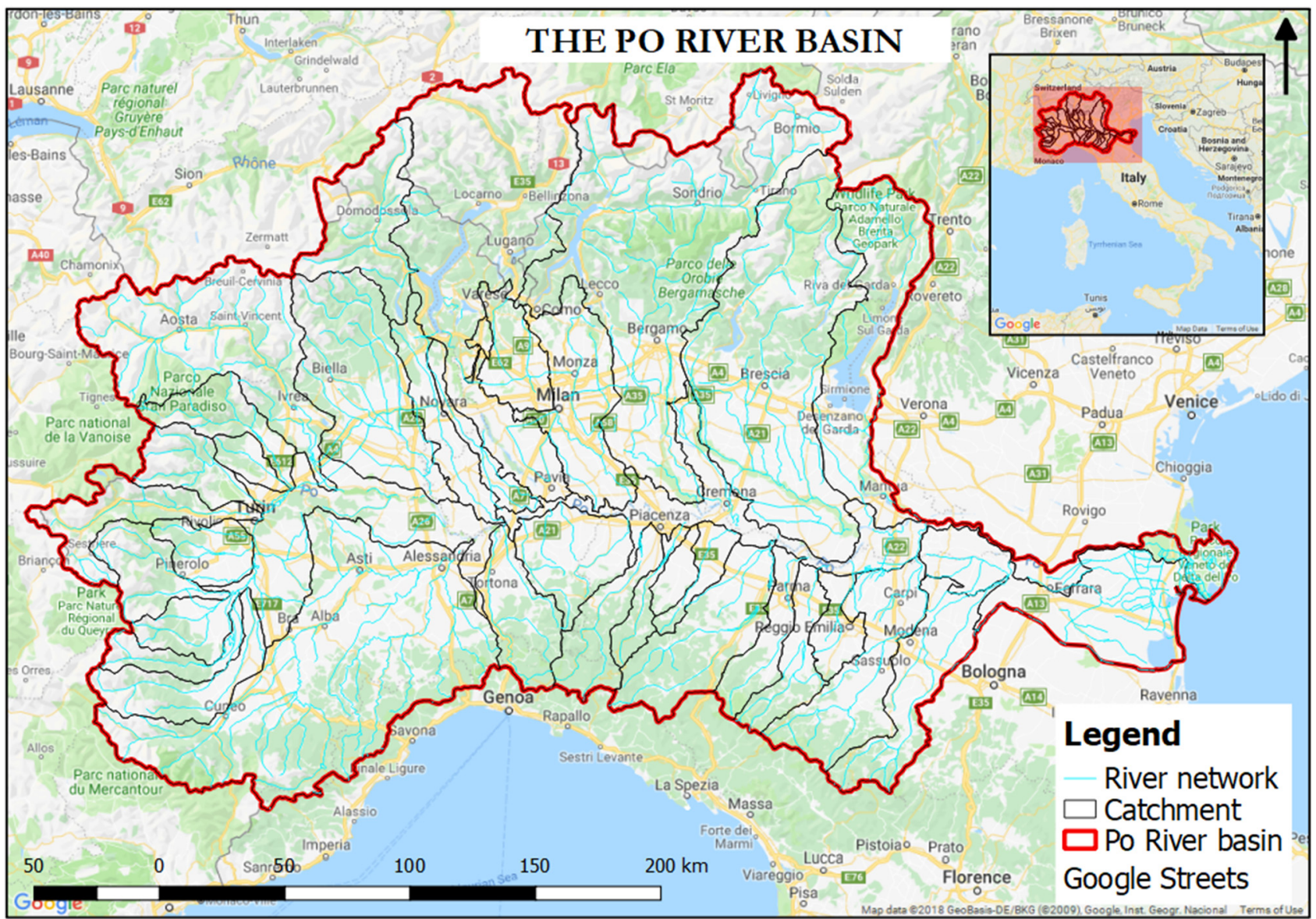

Fig. 2. The Po River basin and its catchment.

Vietnam (Duc and Umeyama, 2011). About 47\% of the RRD area $\left(6700 \mathrm{~km}^{2}\right)$ is used for agriculture or aquaculture, mainly for annual crops, aquaculture, perennial crops, and pasture (90\%, 6.6\%, 3.1\%, and $0.6 \%$, respectively) (Luu et al., 2010). The water resources in this region are used mainly for human consumption, agricultural irrigation, and hydropower generation (Le et al., 2017) (Fig. 3).

There are four large reservoirs located in the RRB, i.e. the Hoa Binh and the Son La reservoirs are in the Da River; the Tuyen Quang and the Thac Ba reservoirs are in the Lo River. In addition, two more dams are recently constructed in the upstream Da River, namely the Huoi Quang dam (operating since December 2015) and the Lai Chau dam (operating since November 2016) (Le et al., 2017).

The RRB has two distinct seasons, namely the wet season (from May to October) and the dry season (from November to April). The average river flow in the basin at Son Tay, a meteorological station in Ha Noi, fluctuates from $8000 \mathrm{~m}^{3} \mathrm{~s}^{-1}$ to $1500 \mathrm{~m}^{3} \mathrm{~s}^{-1}$ (Giuliani et al., 2016). The annual rainfall in the RRB is about $1600 \mathrm{~mm} /$ year of which about $75 \%$ concentrates in the wet season. The annual average temperature, humidity, and evaporation are around $24^{\circ} \mathrm{C}, 80 \%$, and $900 \mathrm{~mm}$, respectively (Duc and Umeyama, 2011).

\section{Application of the conceptual framework to the case studies}

In this section, we discuss the above-mentioned methodological framework and indicators for the selected case studies, namely the RRB and the PRB. For each case study, we first report the projections of changes, including climate change, land use change, and socioeconomic dynamics. Then, we discuss the effects of these changes on FWES using the MEA classification of FWES reported in Fig. 1 and the indicators reported in Table 1. Moreover, we focus our review on the provisioning services and two regulating services (i.e. the water purification and sediment control services) because these are the most important services in the two case studies. Yet, as discussed in the following sections, we report as many indicators as possible for these services both in absolute (e.g. nutrient rate $-\mathrm{kg} \mathrm{ha}^{-1}$ ) or relative value (e.g. the reduction of $53 \%$ in the monthly discharge) where they are available in the literature.

\subsection{Projections of climate change in the Po River basin}

The results from recent researches demonstrated that the temperature would increase almost in the whole PRB during the projected period (until 2100) (Aerts et al., 2013; Vezzoli et al., 2015). Moreover, Aerts et al. (2013) demonstrated that positive temperature anomalies (i.e. increased temperature) in the mountain regions are stronger than those in the delta regions. Additionally, the temperature anomaly is strengthened in the further time frame. For instance, the anomaly of the period (2041-2070) is higher than the one of the period (2021-2050). This projection is consistent with the historical data reported by Ciccarelli et al. (2008), where the average temperature of north-western Italy significantly increased (about $1{ }^{\circ} \mathrm{C}$ ) in the period 1952-2002. This trend was also confirmed by Tibaldi et al. (2010), estimating that the maximum temperature of the PRB increased constantly with a rate of $0.5^{\circ} \mathrm{C}$ every 10 years, equal to $2^{\circ} \mathrm{C}$ since 1960 , and could reach an average increase of $3-4^{\circ} \mathrm{C}$ at the end of this century (Fig. 4).

Similarly, the precipitation of majority areas of the PRB would decrease in the future, especially in the mountain areas (Aerts et al., 2013). Coppola and Giorgi (2009) used downscaled AR4 (the Fourth 


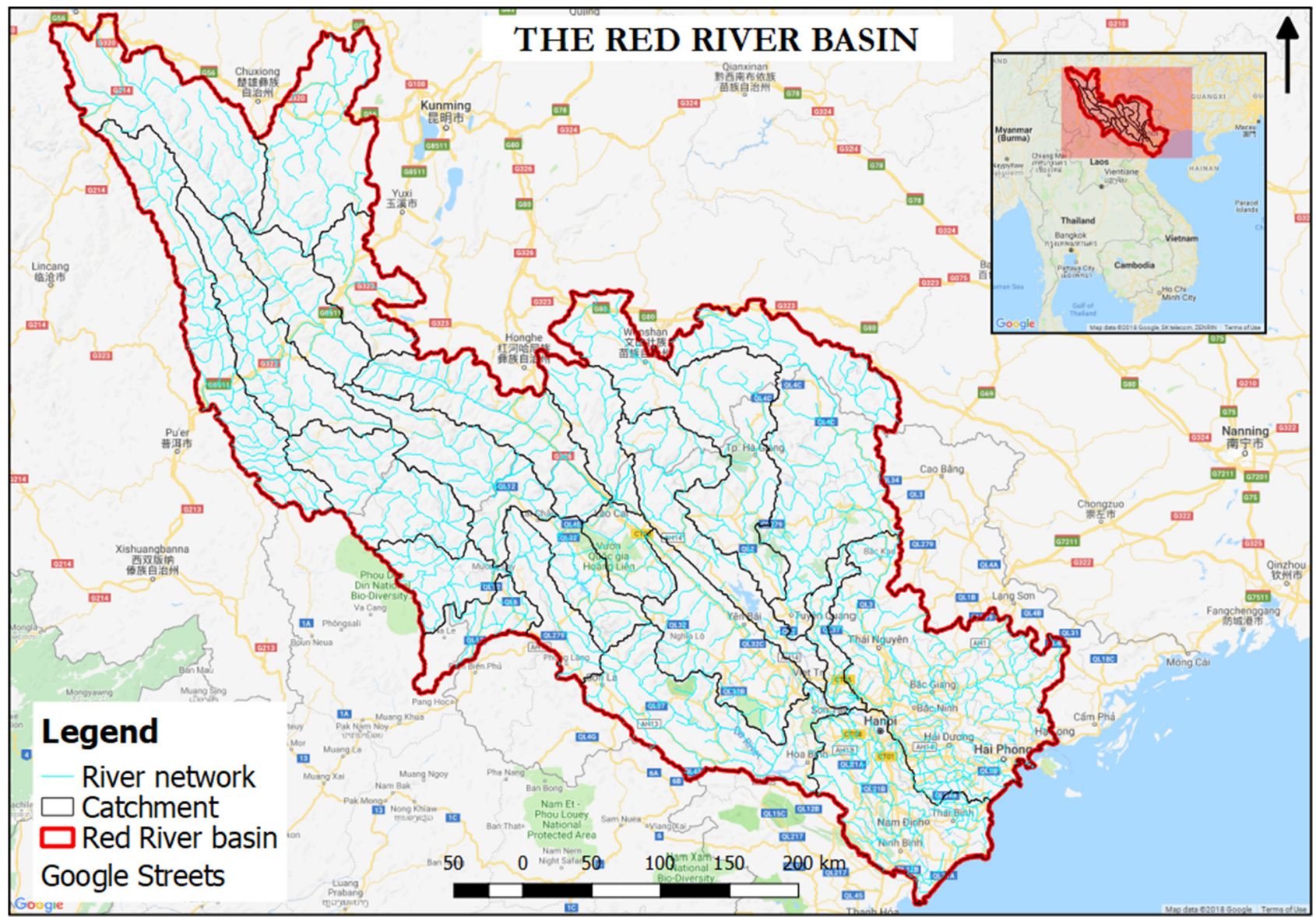

Fig. 3. The Red River basin and its catchment.

Assessment report) climate scenarios (i.e. A2, A1B, B $1^{2}$ ) to simulate the rainfall anomaly in Northern Italy between 1920 and 2100, and projected an overall reduction in rainfall of about $20 \%$, with local peaks of $40 \%$. This result agreed well with observational data reported in Toreti et al. (2009), showing a decrease in rainfall with a rate of $1.47 \mathrm{~mm} /$ year in the observational period 1961-2006.

Concerning seasonal variation, a climate model that was developed by Ravazzani et al. (2014) predicted a remarkable decrease in the precipitation in summer and spring. Yet, the results from RCM COSMOCLM model projected a reduction of precipitation in summer and an increase in autumn and winter within time frame 2041-2070 and 2071-2100 under two climate scenarios, namely RCP4.5 and RCP $8.5^{3}$ (Vezzoli et al., 2015). These results were consistent with another study in the Veneto and Friuli plain (Baruffi et al., 2012), where the rainfall in the period 2071-2100 would decrease in the summertime while precipitation appeared to be $15 \%$ weaker with reference to the period 1971-2000. Finally, it is noteworthy that southern Europe and the Mediterranean region showed a high inter-annual variability in rainfall and temperatures, and an increase of flood events in the last decades (Coppola and Giorgi, 2009; Ulbrich et al., 2013).

\footnotetext{
2 They are the six emission scenarios, which are published and used by IPCC until the Fourth Assessment report. They include A1 (describes a rapid economic growth, global population) with three families (A1FI, A1T, and A1B), A2 (describes a very heterogeneous world), B1 (describes a convergent world), and B2 (describes an economic, social and environmental sustainability world).

${ }^{3}$ Representative Concentration Pathways (RCPs) describe four different 21st century pathways of greenhouse gas (GHG) emissions and atmospheric concentrations, air pollutant emissions and land use. They include a stringent mitigation scenario (RCP2.6), two intermediate scenarios (RCP4.5 and RCP6.0), and one scenario with very high GHG emissions (RCP8.5).
}

Regarding SLR, the observational data in the North Adriatic Sea region indicated that the rate of SLR varied from $1.2 \mathrm{~mm} / \mathrm{year}$ (in Trieste) to $2.5 \mathrm{~mm} /$ year (in Venice). Additionally, the estimate of SLR by a multimodel chain from the Euro-Mediterranean Center on Climate Change (CMCC) and the National Research Council-Institute of Marine Sciences (CNR-ISMAR) for the future scenario 2070-2100 are about $17 \mathrm{~cm}$ and $42 \mathrm{~cm}$ for low and high SLR scenario, respectively (Rizzi et al., 2017).

In conclusion, the major climate-related changes in the PRB include the increase of temperature, evapotranspiration, river load of nitrogen, seawater salinity, and the decrease of precipitation and river discharge (Giani et al., 2012). These above-mentioned changes (either single factor or combination of some factors), on the one side, are affecting FWES in the PRB such as the reduction of freshwater availability, decline of water quality, increased frequency of anoxic events, increased frequency and magnitude of extreme events, increased coastal erosion, and salinization of soil, groundwater and surface water. On the other side, CC and SLR are modifying the demands of freshwater services, i.e. higher water demand for irrigation, water treatment, maintaining environmental flow, and for hydropower.

\subsection{Projections of land use and socio-economic change in the Po River basin}

The historical data showed that the PRB experienced massive changes in land use and land cover. Over the period 2000-2006, the largest loss of forest and semi-natural areas was recorded in Lombardy $\left(26 \mathrm{~km}^{2}\right)$. The largest increases in the artificial surfaces were observed in Veneto $\left(78.72 \mathrm{~km}^{2}\right)$, Lombardy $\left(62.52 \mathrm{~km}^{2}\right)$ and Emilia-Romagna $\left(53.37 \mathrm{~km}^{2}\right)$. The agricultural lands declined by $78 \mathrm{~km}^{2}$ in Veneto, $29 \mathrm{~km}^{2}$ in Emilia Romagna, and $36 \mathrm{~km}^{2}$ in Lombardy (Amadio, 2012).

Regarding land use/land cover in the future, the Land-Use based Integrated Sustainability Assessment model (LUISA) data provides the 

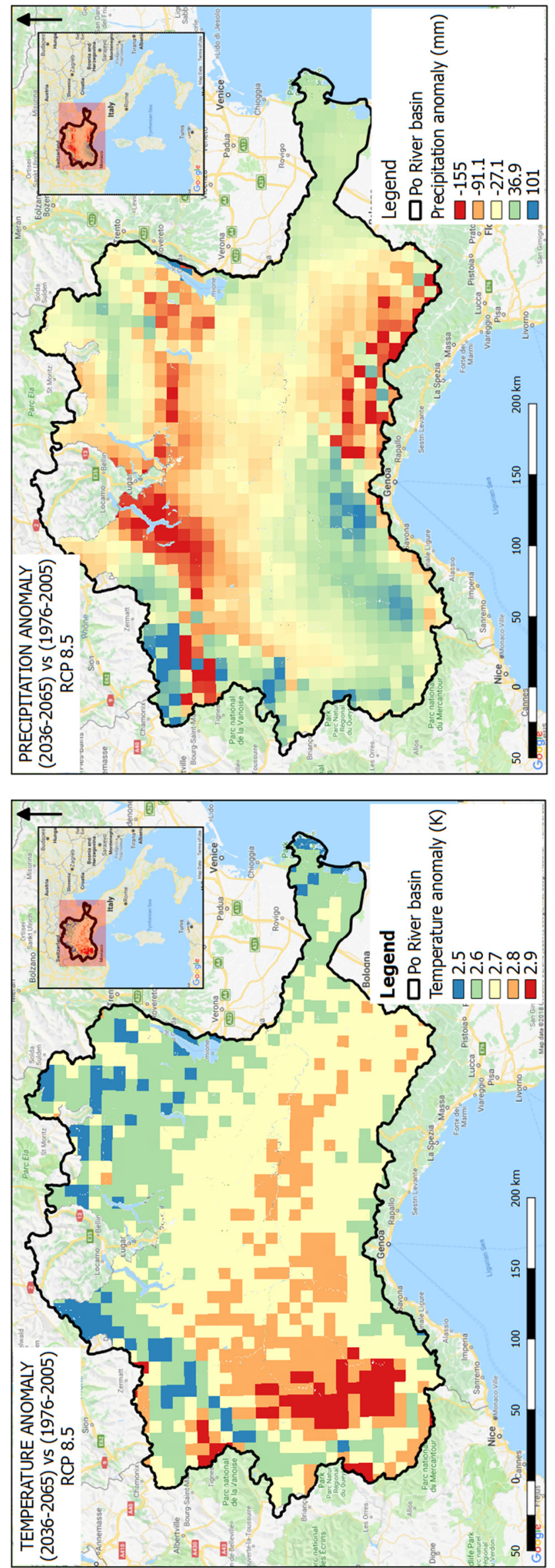
projections of land use in the future (2010-2050) respect to the updated 2014 configuration (Baranzelli et al., 2014). Fig. 5 indicates that artificial areas of the PRB are expected to increase by about $26.07 \%$ in the period 2010-2050 while urban and industry-commercial-services areas are estimated to increase of about $6.2 \%$ in the same timeframe. On the contrary, natural land, urban green leisure areas and water bodies are projected to decrease of about $9.61 \%, 2.15 \%$, and $0.22 \%$, respectively. Regardless of CC, these trends may increase the stress on both the supply side of FWES (e.g. decreasing water availability due to the progressive decline of water bodies) and their demand side (e.g. increasing water demand due to the expansion of urban areas). Nevertheless, land use changes could also trigger some positive trends, which may strengthen FWES. Specifically, a decrease in agricultural areas could lead to decreased water consumption and stress on water quality due to the reduced use of pesticides. In addition, an increase in forest and transitional woodland may increase the precipitation and increase the infiltration capacity of the surrounding rivers, waterfalls, and wetlands.

Regarding the socio-economic dynamics in the PRB, the demographic trend recorded over the 1951-2001 period showed a positive peak (12\%) during the '70s, followed by a stabilization of the growth during 1991-2001 (with a negative trend in metropolitan provinces of Milan and Turin, i.e. 5.0\% and 3.4\%, respectively). The majority of the population of the PRB (about 64\%) lives in the lowland portion of the basin, with higher rates in the metropolitan cores of Northern Lombardy and the Southern Emilia-Romagna (Amadio, 2012). Additionally, the recorded data in the period 1991-2001 indicate that the economic structure was stable with a positive trend in all sectors such as primary (10.7\%), tertiary (18.9\%), and touristic sectors (27.7\%).

In conclusion, despite the future socio-economic of the PRB depends on the European and national policies (e.g. policies on the role/competitiveness of EU countries in the global market), we would expect both a demographic and economic increase in the major cities (e.g. Rome, Milan and Florence), together with an extended suburban sprawl and a diffuse land cover due to the intensification of logistic activities and infrastructures supporting the production (Amadio, 2012).

\subsection{Effects of climatic factors on FWES in the Po River basin}

\subsubsection{Effects on water provisioning services}

Some studies based on the historical data demonstrated that there were decreases in the water volume (Coppola et al., 2014; Ravazzani et al., 2014) and increases in the frequency and the magnitude of extreme events (e.g. floods and droughts) (Coppola et al., 2014). For instance, the observational data indicated a reduction of the $20 \%$ of the annual Po River discharge, measured between 1975 and 2010 (Carrera et al., 2013). Moreover, the analysis of longer data record (1920-2009) demonstrated that there was an increase in the maximum annual river runoff (i.e. $9.24 \mathrm{~m}^{3} \mathrm{~s}^{-1} \mathrm{yr}^{-1}$ ), while a decrease in the minimum one (i.e. $0.18 \mathrm{~m}^{3} \mathrm{~s}^{-1} \mathrm{yr}^{-1}$ ) (Montanari, 2012).

Recently, some authors projected a similar trend for the future. For instance, Pedro-Monzonís et al. (2016) projected an outflow reduction of about $33 \mathrm{~km}^{3}$ in the period (2040-2041) with respect to the reference period (2010-2011) under the climate scenario RCP 4.5, assuming an increase in $\mathrm{CO}_{2}$ emissions until 2040 and a later decrease to less than the present, approximately $4.2 \mathrm{Pg} \mathrm{C} \mathrm{yr}^{-1}$. Furthermore, these negative changes became more complex with seasonal variations. In fact, Ravazzani et al. (2014) demonstrated that monthly discharge in the time period (2041-2050) is expected to increase remarkably in the winter and autumn (279\% in February at Villafranca), and to decrease significantly in the summer ( $-53 \%$ in August at Tavagnasco) with respect to the period (2001-2010). Coppola et al. (2014) concluded that the annual discharge in the period (2020-2050) is expected to decrease in all seasons except winter (December, January and February) with respect to the period (1960-1990). The runoff of the northern parts of the basin is projected to increase by $20 \%$ during winter in low elevation areas and of $40 \%$ at higher elevations. In the fall season (September, October and November), a 20\% discharge decrease was found everywhere, with a maximum of $-40 \%$ in few areas to the far north and south of the basin. Baruffi et al. (2012) reported that, with respect to the reference period (1971-2000), the projected mean winter surface runoff appears to increase by about $60 \%$, while decreasing of about $25-45 \%$ during summer in the period (2071-2100).

As a consequence of the variations in precipitation and runoff, the frequency of extreme events is projected to increase in the future. The projection of the Standard Precipitation Index (SPI) (Aerts et al., 2013) confirmed that extreme events such as extreme wet (SPI greater or equal to 2) and extreme dry (SPI smaller than -2) may occur more often in the future, with a higher magnitude.

These changes are likely to have negative impacts on crop growth and crop yields, water consumption for irrigation and hydropower, the spreading of pests and diseases (Brilli et al., 2014; Lionello et al., 2014). For instance, the outcome of the sub-national Computable General Equilibrium (CGE) model demonstrated that the impacts of flood events were considerable in both absolute and relative terms (i.e. from 3.94 to 10.75 billion euro in values of the year 2000) (Carrera et al., 2015). A study on the socio-economic impact of drought events in the PRB confirmed that although some farmers experienced very severe effects, agricultural sectors as a whole benefited in economic terms due to the "price effect" (Musolino et al., 2017). Other case studies in Val D'Aosta demonstrated that the variation in precipitation pattern would result in a reduction of $10 \%$ in the annual hydropower production (equivalent to $200 \mathrm{GWh}$ ) (Maran et al., 2014). This reduction could affect the electricity demand of 170,000 home users, the stability of electricity market and other water users.

\subsubsection{Effects on water purification services}

Recent studies indicated that there was a strong correlation between extreme events (i.e. floods and droughts) and the transportation of pollutants to surface freshwater. For instance, flood events accounted for at least one-third of the particulate annual export (organic carbon and nitrogen). The suspended organic material during the flood periods was dominated by soil organic matter (Tesi et al., 2013). Chemicals transported by the river, such as dissolved nitrate $\left(\mathrm{NO}_{3}^{-}\right)$, exhibited a strong relationship with the water flow. Their concentration decreased with increasing flow rate due to the dilution processes. During flood events, the concentration of nitrite $\left(\mathrm{NO}_{2}^{-}\right)$and ammonia $\left(\mathrm{NH}_{3}\right)$ showed the same trend but different compared to $\mathrm{NO}_{3}^{-}$because of the positive correlation with the concentration of the suspended material. Additionally, heavy rains and floods caused an increase in sediment load and water turbidity thus reducing water transparency. Variations in light availability in the mixed layer could not only limit algal development but also favor the presence of species tolerant to low light. In contrast to the case of high discharge, lower discharge could lead to a reduction of nutrient loads. For instance, during extremely low discharges like the one occurred in 2005 , nutrient loads in the Po river decreased by $-70 \%$ for dissolved inorganic nitrogen, $-58 \%$ for $\mathrm{PO}_{4}^{3-},-73 \%$ for $\mathrm{SiO}_{2},-50 \%$ for total nitrogen and $-59 \%$ for total phosphorus, comparing with high discharge load as in 1996 (Cozzi and Giani, 2011). Yet, under the extreme dry and warm conditions (e.g. in 2015) the concentrations of nitrates were relatively high (i.e. higher than $10 \mathrm{mg} / \mathrm{l}$ ) (Marchina et al., 2017).

Besides, SLR was predicted to have negative effects on water quality by accelerating upward flux of saline water and increasing the presence of arsenic (As), lead ( $\mathrm{Pb}$ ) and Zinc ( $\mathrm{Zn}$ ) in the shallow portion of the aquifers (Colombani et al., 2016a). Furthermore, saline water was further distributed on the surface water in the catchment through the irrigation networks. Additionally, SLR affected negatively the quality of groundwater via seepage of saline groundwater. Colombani et al. (2016b) confirmed that seepage fluxes could increase and, consequently, the salinization of shallow groundwater and surface waters would intensify in the Po River delta. The authors also projected that 


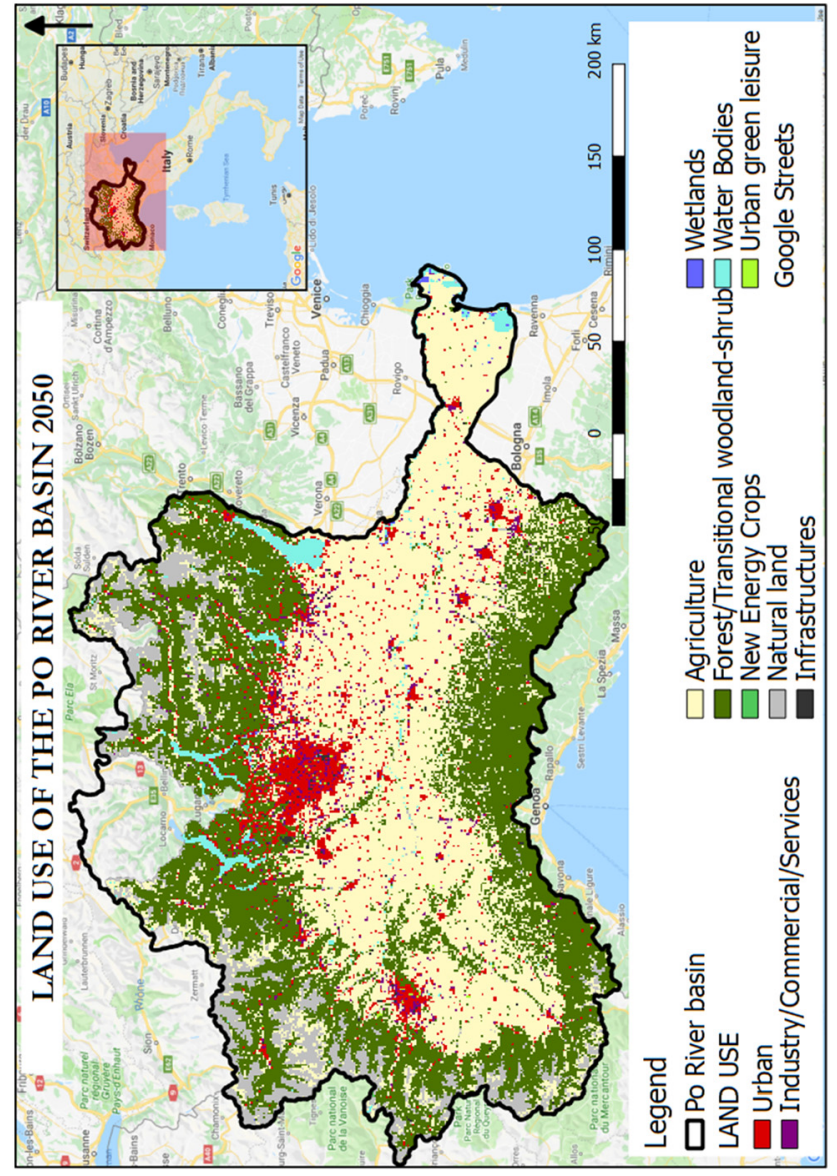

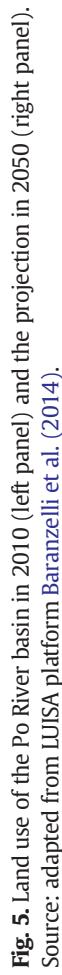

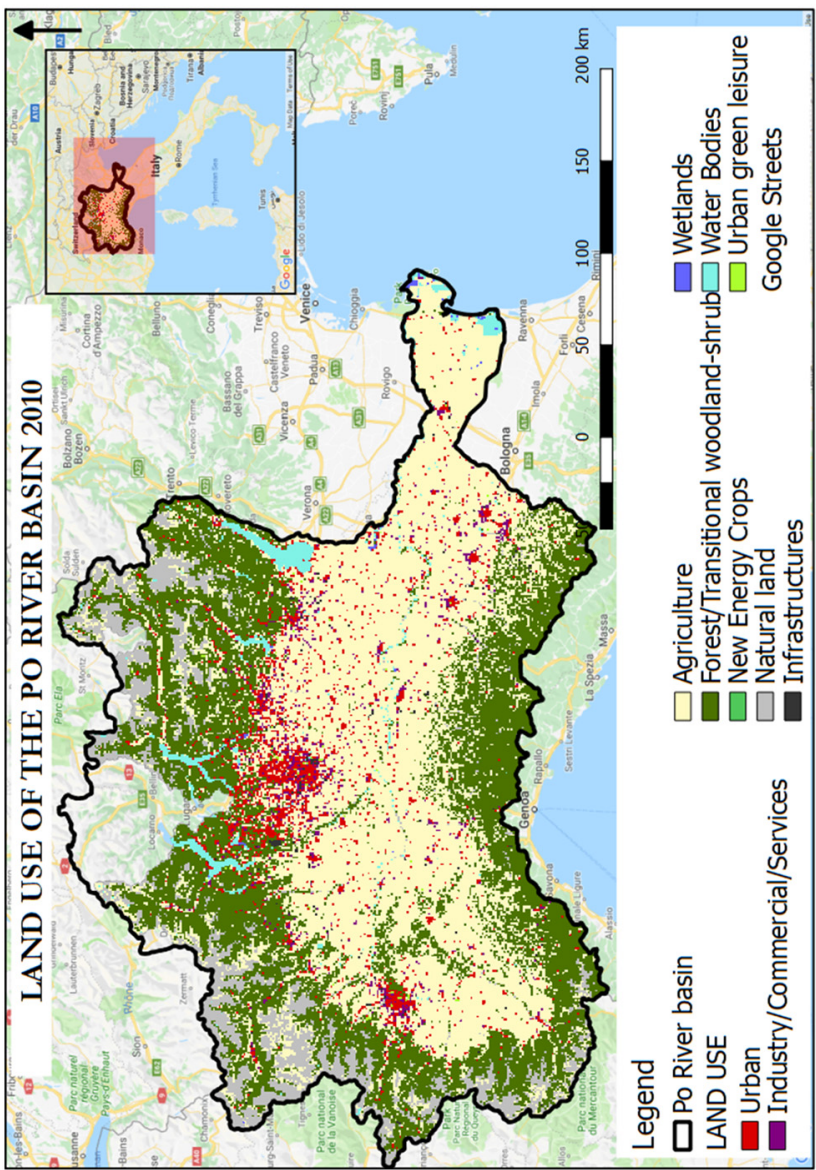


salt loads in drainage canals would increase by $30 \%$ in some areas, and fresh groundwater volumes would be reduced by $46 \%$ by 2050 .

As a consequence of SLR, the mass fluxes of all the examined trace elements (i.e. As, $\mathrm{Pb}$, and $\mathrm{Zn}$ ) increased in Po river delta under the analyzed climate change scenarios (Colombani et al., 2016a). This trend was explained by the increase of those elements in the shallow portion of the aquifer, drained by the reclamation network for irrigation.

\subsubsection{Effect on erosion and sediment control services}

The effects of CC on the coastal sediment dynamics were investigated by Bonaldo et al. (2015) with a complex wave and sediment transport model, fostered by IPCC A1B emission scenario within the period (2070-2099). The authors concluded that there was a reduction of $10-20 \%$ in the long-shore transport regime, while the effects on crossshore transport were generally negligible for ordinary storms (with a return period shorter than 1 year) but could decrease up to $10 \%$ for extraordinary events (with a return period longer than 10 years). These modifications would affect morphology and coastal line evolution in the long timescale.

\subsection{Effects of non-climatic factors on FWES in the Po River basin}

\subsubsection{Effects on water provisioning services}

Anthropogenic interventions in the PRB (e.g. land use changes and agricultural activities) induced some negative consequences on water provisioning services. For instance, the results of a case study on a reclaimed area located in the PRB shown that land use changes had significant impacts on hydrological-hydraulic behaviors. Particularly, the simulated peak flows markedly increased from the 1955 land use scenario to that of 1992, significantly increasing the flood risk in this reclaimed area (Camorani et al., 2005). Moreover, these authors suggested that the expansion of agriculture and or industrial areas could result in an increase of flood risk for less severe frequency rainfall events.

Indeed, the management plan of the Po River Basin District identified that the expansion of agricultural areas had negative effects on the provisioning of freshwater. Specifically, in the Mediterranean area, the water demand of the agricultural system would increase in response to $\mathrm{CC}$, due to the need of compensating the reduction of rainfall. Additionally, the higher temperature may shift the activity period of pests and diseases in the growing season, causing higher consumptions of chemical products (i.e. pesticides) (Brilli et al., 2014).

\subsubsection{Effects on water purification services}

The last survey of the Italian National Institute for Environmental Protection and Research (ISPRA) over the national territory reported that pesticides were found in $63.9 \%$ of 1284 monitoring points distributed on surface waters of the whole Italy. In 274 monitoring points, the pesticide concentrations were found over the quality limit and $89.4 \%$ of these were located in the region of the Po River Basin District. The main pollutants of the Po River were total nitrogen, i.e. $\mathrm{NO}_{2}^{-}, \mathrm{NO}_{3}^{-}$, $\mathrm{NO}_{4}^{+}$; total phosphorus, i.e. $\mathrm{PO}_{4}^{3-}$; $\mathrm{SiO}_{2}$; total organic carbon; and total suspended matter (Cozzi and Giani, 2011). Published data for the Po river indicated that total nitrogen transport increased by about two times during the last three decades. The highest record was about $173.10^{3} \mathrm{t} \mathrm{yr}^{-1}$, which was reported for the years 1996-2000, due to a constant increase of anthropogenic emissions not fully compensated by the improvements of wastewater management. Castaldelli et al. (2013) argued that farming practices and intensive agricultural activities posed the risk of excess soil mineralization and progressive loss of denitrification capacity in this area.

Concerning macronutrients, Pieri et al. (2011) investigated the quality of water draining from three watersheds, totally or partially cultivated, by determining chemical indicators $\left(\mathrm{NO}_{3}^{-}\right.$and $\mathrm{NH}_{4}^{+}$ concentration, $\mathrm{N}$ balance), trophic status (chlorophyll-a concentration) and benthic population indexes. From their research, they found the correlation between chemical parameters and land use management and farming practices. Specifically, intensive agricultural activities are linked to the high $\mathrm{NO}_{3}^{-}$concentration in water. Moreover, the chlorophyll-a concentration followed the same trend, depending on nitrogen loads. The macronutrient pollution was also investigated by the Po River Basin Authority in five sub-basins at municipality level: Agogna, Oglio (lake downstream), Trebbia, Enza and Secchia. From a preliminary estimation performed by a multiple regression analysis, a significant correlation was found between the amount of the total dissolved nitrogen and the population density/livestock load $\left(\mathrm{R}^{2}=\right.$ 0.85); and between the amount of the total dissolved phosphorus and population density $\left(R^{2}=0.93\right)$ (Autorità di Bacino del Fiume Po, 2015).

\subsubsection{Effect on erosion and sediment control services}

A case study on Reno River, located in the lower part of the PRB, investigated the impacts of intensive engineering works (e.g. headwaters, dam construction, torrent control works, and bed material mining) on channel modification and sediment budget. The comparison of four different longitudinal profiles surveyed in 1928, 1951, 1970 and 1998 shown that the bed incision rate in the lower parts of the Reno river, from Bologna to the mouth (about $120 \mathrm{~km}$ ), was about $3.78 \mathrm{~m}$, with peaks of $>6 \mathrm{~m}$ (Preciso et al., 2012). This streambed degradation led to a reduction of bedload transport rates, which might limit sediment supply downstream of Reno River. Besides, while the impoundment of reservoirs and mobile barrage for hydropower resulted in the local interruption of sediment transport, sand mining changed significantly river morphology and affected transportation activities (Lanzoni et al., 2015).

\subsection{Projections of climate change in the Red River basin}

Fig. 6 reports the spatial distribution of anomalies of maximum monthly temperature and those of precipitation between historical data period (1960-1990) and projection period (2061-2080) under the climate scenario RCP8.5.

This figure demonstrates that the maximum monthly temperature would increase in the whole basin, from 2.74 to $3.16{ }^{\circ} \mathrm{C}$ by 2080 under the climate scenario RCP 8.5. Giuliani et al. (2015) also concluded that the mean daily temperature is projected to increase in the entire basin, reaching an anomaly of $4{ }^{\circ} \mathrm{C}$ by 2098 under the A1B emission scenario. This projection is consistent with the results reported in Weiss (2009), i.e. the temperature anomaly would reach about $2-4{ }^{\circ} \mathrm{C}$ by 2100 with respect to the reference period 1980-1999.

Total mean monthly precipitation is expected to increase over time in the entire catchment with a monotonic trend in almost all the subbasins, varying from 3.5 to $15.1 \mathrm{~mm}$. This result is consistent with Chaudhry and Ruysschaert (2008), where annual total rainfall is expected to increase in the range of $2.5-4.8 \%$ by 2050 and $4.7-8.8 \%$ by 2100 , compared to 1990 . Nevertheless, these anomalies have not any even distribution, i.e. decrease in July and August and increase in September and November (Weiss, 2009). More generally, in the northern part of Vietnam, rainfall and daily rainfall intensity would increase of $10-20 \%$ over in the future period 2061-2090, compared with the reference period 1961-1990 (Raghavan et al., 2017).

Regarding SLR, Vietnam is experiencing an upward trend of about 2-3 mm per year (Weiss, 2009). The report of Ministry of Natural Resources and Environment stated that the sea level would increase about $30 \mathrm{~cm}$ by 2050 and about $75-100 \mathrm{~cm}$ by 2100 , compared with the average mean sea level of the period 1980-1999 (Duc and Umeyama, 2011; Ha and Pintor, 2014). Consequently, the coastal areas could be affected by saltwater intrusion into aquifers and groundwater resources, leading to the reduction of freshwater availability. Specifically, the coastal areas of the RRB would experience varying levels of damages due to SLR and storm surge flooding. Especially, areas at lower elevations would be flooded more completely and for longer periods, causing greater damages, while areas at higher elevations would experience less severe impacts. 

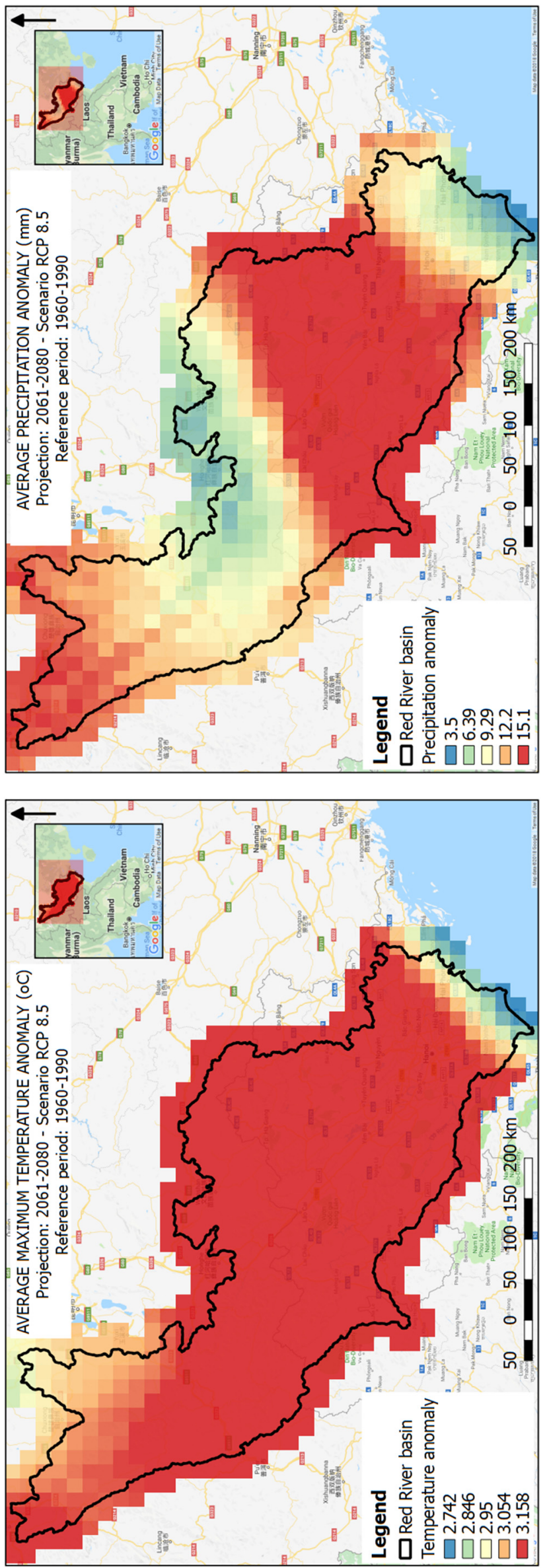
Overall, CC is expected to increase climate variability in Vietnam, decreasing rainfall during the dry season and increasing rainfall in the wet season. Additionally, SLR would lead to permanent inundation of a significant portion of the low-lying Red River delta areas (Neumann et al., 2015). CC is also expected to have considerable impacts on Vietnam's fishery and aquaculture sectors, which accounted for 3.9\% of GDP in 2005 (Chaudhry and Ruysschaert, 2008).

\subsection{Projections of land use and socio-economic change in the Red River basin}

Fig. 7 shows the distribution of different types of land use in the RRB in 2010 and the projection of land use in 2050 under the climate scenario B2 (Li et al., 2017). Under this scenario, farmland and urban areas are expected to expanse (i.e. $37.29 \%$ and $58.17 \%$, respectively) while forest and grassland areas are expected to collapse (i.e. $20.36 \%$ and $34.52 \%$ ) in the RRB. The intensively cultivated areas such as irrigated, rainfed, mosaic croplands and aquatic regions are mainly located in the lower part of the RRB (Arino et al., 2010).

The historical data showed significant changes in some land use classes such as agriculture, forest and exclusive land. Specifically, agricultural land area dropped by about 5.5\%, from 1.97 million ha in 2003 to 1.86 million ha in 2011 (Simone et al., 2013). In the same period, forestland increased from 3.27 million ha to 4.42 million ha, leading to a percentage increase of forest coverage from $36.2 \%$ to $48.9 \%$. Additionally, exclusive land area increased from 0.63 million ha to 0.72 million ha in the whole basin. These changes would become more complex in the future depending on climate and socio-economic conditions. For instance, the build-up land would expand in clusters around the largest cities such as Ha Noi and Hai Phong due to urban population growth (Van Dijk et al., 2012). This expansion was driven by the presence of industrial areas and infrastructure located in suburban areas at a distance of about $70-140 \mathrm{~km}$ from these big cities.

Regarding socio-economic dynamic of the RRB, according to the Provinces report in 2009, the economic growth rate was about 8-12\% per year, in which the industrial growth was about 15-30\% (higher than the national average rate) and the urban population growth was about 35\%. Nevertheless, the industrialization was not uniform. While higher industrialization rates (over 20\%) were observed in Hanoi, Quang Ninh, Hai Phong, Hung Yen, Hai Duong and Vinh Phuc, the lower ones were detected in the agricultural-based provinces such as Thai Binh, Ninh Binh, Nam Dinh, Phu Tho, and Ha Nam (Trinh, 2009). In addition, many towns were upgraded to cities, such as Thai Binh, Phu Ly, Ninh Binh, Hai Duong, Hung Yen, Bac Ninh and Vinh Yen.

Several development objectives were targeted in the Master Plan for the socio-economic development in the RRD through 2020 (Minister, 2013). Specifically, the socio-economic targets were set for 2020 , such as increasing the region's contribution to country's GDP from $24.7 \%$ (in 2010 ) to $28.7 \%$; increasing the average income per capita to around USD 4180 ( 1.3 times of the national average); the region's average population growth would be around $0.93 \%$ in the $2011-2020$ period and region's population would reach 21.7 million. Obviously, all these targets would increase stress on FWES on both supply side and demand side. In addition, numerous environmental promotion objectives were targeted to eliminate environmental pollution in both rural and urban areas to ensure sustainable development, such as treating at least 95\% of medical waste, and centralizing wastewater treatment systems for at least $85 \%$ of operating industrial parks and export processing zones.

\subsection{Effects of climatic factors on FWES in the Red River basin}

\subsubsection{Effects on water provisioning services}

The main climatic factor affecting freshwater provisioning in the RRB is the precipitation related to the South Asia Summer Monsoon (SASM) and El Nino Southern Oscillation (ENSO) (Gao et al., 2015). These authors found a positive correlation between precipitation and river discharge, confirming the high dependence of discharge on precipitation. They also observed the decrease in river flows and water levels in many dams and reservoirs, particularly during El Niño years. These changes were dominated by precipitation and closely related to the SASM and ENSO. Specifically, El Niño events over the RRB might induce lower water discharge with possible droughts. La Niña events might cause higher water discharge with possible flood events (Gao et al., 2015). Duong et al. (2016) found that the mean monthly discharge increased of about $20-40 \%$ in the wet season and decreased up to $30 \%$ during the dry season in the period (2026-2035), respect to reference period (1979-2003). Additionally, these authors projected that the magnitude of high flow regimes would increase of $20-60 \%$, while the magnitude of low flow regimes would slightly decrease of $10-20 \%$.

Consequently, these changes would increase water deficit, water shortages, conflicts and competitiveness among water users (e.g. agriculture, water supply and hydropower) with relevant impacts on the supply side of FWES. Since irrigation is the most important freshwater usage, the lowering of the water level in the Red River and its canal network would reduce the irrigated ability and, consequently, the crop productivity. Yet, decreased river water levels and river water discharges would lead to further saltwater intrusion in the coastal areas and their neighbors. It is also expected that flood events would increase in both magnitude and frequency due to increased high flow regimes in the flood season.

In addition to water volume variations, extreme events (e.g. storm surge events) were expected to occur more frequently due to SLR (Neumann et al., 2015). These authors augured that the historical 100year event in Ha Noi would happen every 65 years, 59 years and 49 years by 2050, corresponding to the low SLR, medium SLR, and high SLR scenarios, respectively. As a consequence of these extreme events, over $70 \%$ of areas with high-valued land uses, such as urban residential, rural residential, commercial and industrial uses would be at risk of flooding. In addition, over $90 \%$ of rice paddies would suffer from floods.

\subsubsection{Effects on water purification services}

One of the main drivers affecting the freshwater purification services in the RRB is SLR. The Ministry of Natural Resources and Environment reported that the saltwater intrusion extent had already increased of $7-15 \%$ in the period (1965-1985), with respect to the reference period (1993-2007). Duc and Umeyama (2011) predicted that saltwater intrusion would increase up to $31-50 \%$ when SLR would reach $100 \mathrm{~cm}$, by the year 2100. Positive correlations between the extent of salinity intrusion and SLR were found in all branches of the Red River such as Tra Ly, Ninh Co and Day. At Tra Ly branch, the location of 1-psu salinity (the upper threshold value for drinking water) would increase of $7 \%, 26 \%$, or $40 \%$ over the present distance when the SLR would be $+30 \mathrm{~cm},+75 \mathrm{~cm}$, or $+100 \mathrm{~cm}$, respectively. The corresponding values would be $13 \%$, $24 \%$, and $50 \%$ for the Red River; $8 \%, 23 \%$, and $31 \%$ for the Ninh Co; and $10 \%, 23 \%$, and $29 \%$ for the Day. The location of 4-psu salinity (the marginal value of irrigation water) would change noticeably when the sea level would increase up to $100 \mathrm{~cm}$. Consequently, the increased rate of the extent of salinity intrusion would be $43 \%$ for the Tra Ly, $47 \%$ for the Red River, 33\% for the Ninh Co, and 37\% for the Day (Duc and Umeyama, 2011). Thus, it was foreseen that SLR and its alterations would affect FWES. On the supply side, SLR would reduce inland territory as well as cultivation areas. Moreover, the salinity intrusion would further decrease the availability and quality of surface and groundwater in coastal areas and their nearby.

\subsubsection{Effect on erosion and sediment control services}

Duc et al. (2012) analyzed the impact of SLR on the erosion rate in coastal areas of the Red River delta. The raw estimation data at the south Hai Thinh commune were approximately 0 and $11 \mathrm{~m} / \mathrm{y}$ during the period 1965-1985 and 1985-1995, respectively. The author 

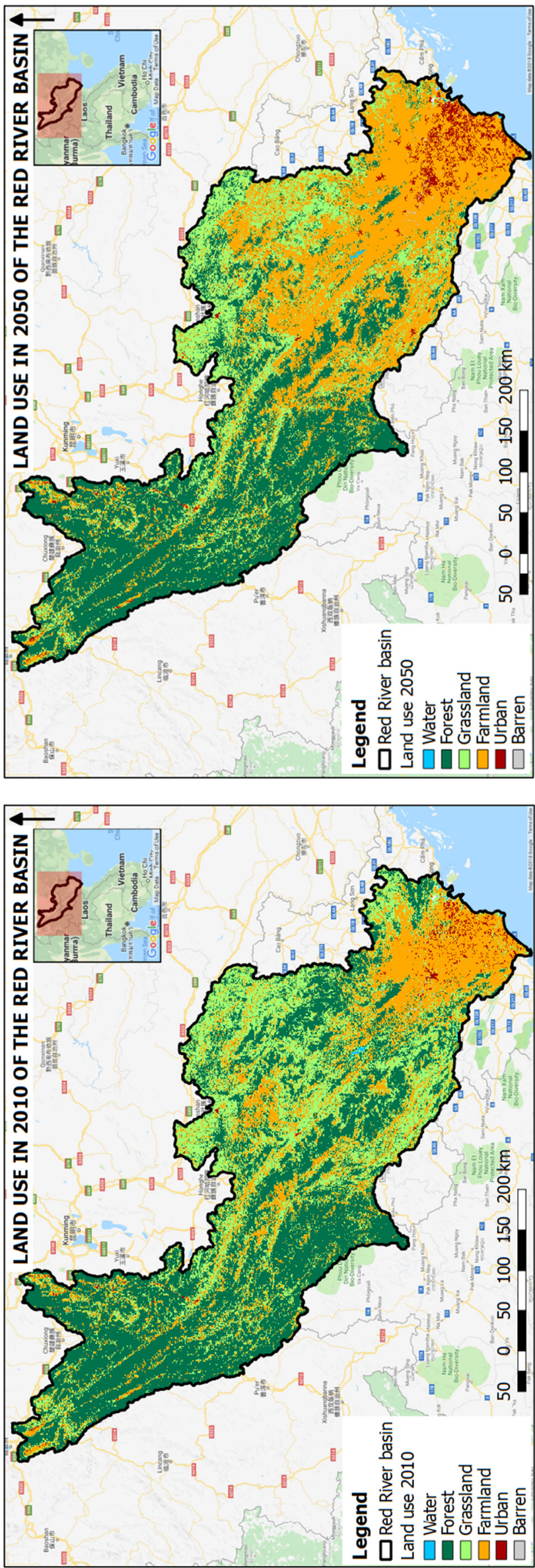

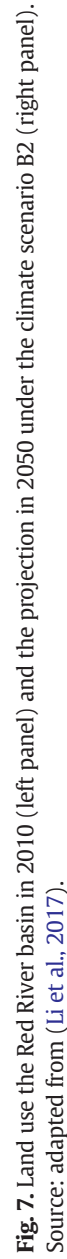


concluded that the erosion rate increased by $12 \%$ from 1995 to 2005 due to SLR.

Regarding sediment load, with respect to the conditions of the period 1997-2004, the model predicted an increase of about $20 \%$ of the suspended matter load, i.e. from 40 to $48.10^{6} \mathrm{t} \mathrm{yr}^{-1}$, due to enhanced rainfall, with an increase of $10 \%$ in rainfall and an increase of $5 \%$ in potential evapotranspiration (Le et al., 2007). Van Maren (2007) reported that sediment was transported along the Red River and was deposited close to the river mouth with the rate of 20 to $25.10^{6} \mathrm{t} \mathrm{yr}^{-1}$ at Ba Lat river mouth.

\subsection{Effects of non-climatic factors on FWES in the Red River basin}

\subsubsection{Effects on water provisioning services}

Dams construction is the main factor affecting the water availability and the water distribution in the RRB (Gao et al., 2015). First, the impoundment and the regulation of the Hoa Binh dam (HBD) has led to the reduction of water discharge in the wet season (14\% in the Red River at Son Tay) and the increased of water discharge in the dry season (12\% at the same station) (Vinh et al., 2014). This result was consistent with Gao et al. (2015), showing that after the regulation of the Hoa Binh dam (from 1990), water discharge increased in January-May while decreased in June-December. Overall, a downward trend of annual discharge was observed, from $3541 \mathrm{~m}^{3} \mathrm{~s}^{-1}$ to $3300 \mathrm{~m}^{3} \mathrm{~s}^{-1}$ at the Son Tay station before and after the construction of the Hoa Binh reservoir, respectively (Lu et al., 2015).

Additionally, the impoundment of the Hoa Binh reservoir affected the water distribution among tributaries of the RRB. Specifically, the water discharge ratio of the estuaries in the north of the RRD slightly increased after impoundment, ranging from $15.5 \%$ to $16.5 \%$ for the Cam and Bach Dang estuaries, from 3.5 to 3.7\% for the Lach Tray River, from 13.6 to $14.5 \%$ for the Van Uc River, and from 6.0 to $6.4 \%$ in the Thai Binh River (Vinh et al., 2014).

Consequently, the impoundment and operation of reservoirs would have strong impacts on FWES and human being. For instance, depending on the climate scenario and the time horizon, the operation of reservoirs would change on average from -7 to $+5 \%$ in hydropower production, +35 to $+520 \%$ in flood damages (Giuliani et al., 2016). By integrating future climate on the current operations, we could reduce the loss of hydropower to 5\%, potentially saving around 34.4 million US\$ $\mathrm{yr}^{-1}$ at the national scale.

Other factors affecting the provisioning services are the change in land use/land cover (e.g. the increase of forest cover) and soil conservation practices (e.g. strip grass barrier, contour hedgerow system, and crop residue) (Ngo et al., 2015). A study concerning the distribution of land cover in the RRB, based on the Globcover 2009 dataset (Arino et al., 2010), indicated that the total irrigated area was about 869,029 ha (Simons et al., 2016). Therefore, changes in land use/land cover (e.g. from agricultural fields to industrial areas) could significantly affect water consumption, water quality, evaporation rate and, ultimately, FWES. For instance, change in land use type between 1995 and 2005 from forest to field crop and urban areas strongly contributed to an increase in the average annual runoff from 182.5 to $342.7 \mathrm{~mm}$. Finally, a decrease of runoff from 342.7 to $167.7 \mathrm{~mm}$ between 2005 and 2010, was due to the expansion of forested areas and the application of soil conservation practices (Ngo et al., 2015).

\subsubsection{Effects on water purification services}

Land use and land cover are the main factors affecting the nutrient cycle and biomass production in the RRB. A study in the Red River estuary, using LOICZ-CABARET budget model, indicated that mangrove system was a net sink of nutrient, i.e. its sequestration rate was about $26,000 \mathrm{~kg} \mathrm{~N} \mathrm{~d}^{-1}$ and $3100 \mathrm{~kg} \mathrm{P} \mathrm{d}^{-1}$ for their biomass production (Wösten et al., 2003). The authors also explored that these rates would change in the future corresponding to different scenarios. For instance, either increasing river discharge in combination with constant river nutrient concentration or constant river discharge in combination with increasing river nutrient concentration would result in increasing nutrient concentration in estuary areas. Beside the role of the primary source of energy and nutrients, mangrove forests had positive roles in the stabilization of shorelines, minimizing wave damages and trapping sediments (Bao, 2011). The protection level of this ecosystem depended on their structure, characterized by the high, the density and the bandwidth. Moreover, the conversion from mangrove forests to agriculture or aquatic areas induced strong alterations in soil properties and carbon dynamics, i.e. mangrove clearing not only turned a mangrove from a carbon sink to a carbon source, but also from a sink to a source of trace metals (Grellier et al., 2017). This result was consistent with Ha et al. (2018), i.e. mangrove forests had a high potential for storing below ground.

Additionally, human disturbances such as untreated sewage from metropolitan cities and runoff from agricultural fields had significant impacts on FWES in term of quantity (e.g. higher demand for agriculture) and quality (e.g. through anoxic conditions, high nutrient concentration and low dissolved oxygen condition) (Hoang et al., 2018; Viet et al., 2018). The water demand for agriculture would increase about 8 bills $\mathrm{m}^{3} \mathrm{yr}^{-1}$ (from 13.65 bill m$^{3} \mathrm{yr}^{-1}$ to 21.5 bill m$^{3} \mathrm{yr}^{-1}$ ) in 2020 due to the expansion of agriculture. Yet, the distribution and structure of phytoplankton and zooplankton in the Day River, a part of the Red River, depended on physical, chemical and biological factors, affecting by human activities such as changes in the nutrient form of freshwater effluence.

\subsubsection{Effect on erosion and sediment control services}

The impoundment of the Hoa Binh reservoir had strong effects on sediment discharge and carbon budget in the Da, Red and Duong rivers. The annual total suspended sediment discharge of the Da River before and after the presence of HBD were $65.0 \times 10^{6} \mathrm{t} \mathrm{yr}^{-1}$ and $5.8 \times 10^{6} \mathrm{t} \mathrm{yr}^{-1}$, respectively. Consequently, the annual total suspended sediment of the Red River at Son Tay reduced to 46 $\times 10^{6} \mathrm{t} \mathrm{yr}^{-1}$ after the impoundment (i.e. a reduction of $61 \%$ ), corresponding to a decrease in the average carbon from $1030 \mathrm{mg} \mathrm{L}^{-1}$ to around $400 \mathrm{mg} \mathrm{L}^{-1}$ (Vinh et al., 2014). Dang et al. (2010) concluded that the presence of the Hoa Binh reservoir on the Da River system reduced the flow velocity, consequently, leading to the accumulation of sediments in the reservoir. Approximately, the mean annual sediment trapped by the Hoa Binh reservoir was estimated at 53.7-81.6 $\times 106 \mathrm{t} \mathrm{yr}^{-1}$, accounting for a reduction of $52 \%-80 \%$ of the total suspended particulate matters flux at the Son Tay site. Furthermore, the impoundment and operation of the Son La dam, on the Da River, upstream of the Hoa Binh reservoir, would further decrease the suspended load by about $50 \%$. Finally, the construction of the Thac Ba reservoir in the Chay river and the Tuyen Quang reservoir in the Gam river resulted in a reduction of about $95 \%$ and $71 \%$ of suspended sediment load, respectively (Ranzi et al., 2012).

Besides, land use and land cover change affected the sediment load in the RRB. Specifically, the conversion of $11.07 \%$ forestland to agricultural land caused an increase of $8.94 \%$ in sediment load in Cau River Catchment (Khoi and Suetsugi, 2014). Ranzi et al. (2012) showed that a $35 \%$ decrease in forest areas, of which $20 \%$ was converted into rice fields and agricultural crop areas and $15 \%$ was converted into bushes, shrubs and meadows, resulted in a $28 \%$ increase in sediment load of the Lo River. Khoi and Suetsugi (2014) also reported that a decrease of $14.07 \%$ in forest and an increase of $14.89 \%$ in cropland led to an increase of $25.4 \%$ of sediment load.

\section{Discussion and conclusions}

The proposed conceptual framework, together with the list of selected indicators, provides a comprehensive overview of FWES including their interaction with the socio-economic system. Yet, it also 
highlights the main impacts of global changes on the supply side and the demand side of the ecosystems. These tools provide the basic instruments to identify and classify the main stressors and impacts of global drivers (e.g. climate change and human activities) on FWES, while conducting a risk assessment. When applying this framework to the Red River basin and the Po River basin, we encountered difficulties to find information about all the selected indicators, due to the incompleteness of literature and the inconsistency of terminology and classification among different authors and publications. Nevertheless, these challenges highlighted the following important aspects in both case studies.

In the PRB, CC could affect the ability of freshwater ecosystem to provide supplies by altering water quantity (e.g. water volume/level) and quality (e.g. salt instruction of surface and groundwater). Yet, CC could increase the frequency and magnitude of extreme events in autumn and spring, with an intensification of damages on human activities. Moreover, the higher temperature could shift the time of flows, with a shift from a winter minimum to a late summer minimum, and an increase in the severity of droughts in summer. Yet, the higher temperature would increase water demand for all water usages, namely irrigation, domestic and hydropower. Consequently, we would expect some negative changes on both the supply and the demand side of ecosystem services, i.e. decreasing in water availability and increasing water consumption. Therefore, we argue that extensive regulation and technological improvements are needed to reduce the conflict and competitiveness among water users in the future.

Besides the climatic factors (Section 3.3), the expected demographic growth, urbanization and industrial progress would have great impacts on FWES through land use change, landscape modification, increased demand and pollutions. Because of industrial, agricultural and household pollutants, excessive organic content in surface water could cause eutrophication in rivers and lakes. Yet, groundwater is continuously contaminated by a high concentration of nitrates originated from fertilizer consumption in agriculture. Therefore, there is a need for reinforcing water regulations to cope with these non-climatic drivers and to maintain the function of FWES.

In the case of the RRB, the main climatic factors affecting FWES are the reduction of water availability in the delta part due to decreased precipitation; the SLR and storm surge events altering these services in the coastal areas due to saltwater intrusion. Noticeably, these impacts are not separable, but they are interacting and magnifying each other. For instance, the lower water levels in rivers, canals, and groundwater table lead to the intrusion of saltwater, that is further altered by SLR.

Besides the climatic factors (Section 3.7), the impoundment and regulation of cascade reservoirs along the main streams is the major anthropogenic factor altering FWES in the RRB. On the one side, the operation of the four big dams (i.e. Hoa Binh, Thac Ba, Tuyen Quang, and Son La) protected the population of the RRB, especially the Ha Noi capital, from flood risks, thus reducing significantly damages and losses. On the other side, this operation changed the natural regime, water availability, water level and, consequently, aquatic diversity. Moreover, the operation of upstream reservoirs in China had clear influences on the flow regimes in the Vietnamese part (Phuong Nam and Van Anh, 2010). Therefore, we emphasize the importance of the regulation of multi-reservoir and the cooperation with Vietnamese neighbors in managing shared river basins.

Additionally, the demographic and urbanization development are other stressors for FWES. On the supply side, urbanization and industrialization would reduce water body areas, leading to the reduction of freshwater availability. Yet, water pollution from the domestic and industrial areas is the main factor contributing to the degradation of water quality in many rivers and lakes such as the part of Nhue River in Ha Noi, creating pressures on the freshwater ecosystems. On the demand side, urbanization and industrialization are expected to increase the water consumption (e.g. demand for wastewater treatment). Thus, in order to ensure sustainable development and maintenance of FWES in RRB, it is necessary to comply with the environmental objectives targeted in the Vietnamese Master Plan (e.g. treating medical waste, centralizing wastewater treatment systems) and the related environmental regulations.

In summary, the effects of global change on FWES vary in time and space, depending on geographical, climatic and socio-economic conditions. Specifically, while CC is considered as one of the main drivers of changes for FWES in the PRB, human activities (i.e. impoundments and dams operations) are considered as the major drivers of ES alterations in the RRB. Secondly, in these case studies, most of the current researches focus on the provisioning and regulating of FWES, namely water quantity and water quality, while other services such as cultural, and supporting services have not been well investigated yet. Finally, even though CC and human interventions affect FWES on both the supply and demand side, these impacts are mainly investigated on the supply side while those on the demand side are under-presented in both case studies. In fact, it is not straightforward to separate the impacts into these two categories, due to the complex dynamic interactions between the natural system and the socio-economic system.

To conclude, since FWES have not been explicitly targeted as the assessment endpoints in the analyzed case studies, we propose that future research on FWES shall define a common and consistent terminology, and classification regarding drivers (e.g. climatic and non-climatic drivers), FWES components (e.g. provisioning, regulating, cultural, and supporting services), and freshwater ecosystem categories (e.g. supply and demand side). These efforts could enhance the utility of past and current knowledge for the definition of climate change adaptation measures and risk mitigation strategies at different scales (e.g. local, national, regional and global scale). Moreover, it is important to address the potential compound effects of different CC components (i.e. the impacts related to combinations and interactions of climate-related hazards) as well as the synergy and potential cumulative effects of climate and non-climate factors, by using interdisciplinary multi-risk modelling approaches.

\section{Acknowledgement}

This work was supported by the project "Efficient Practices of Land Use Management Integrating Water Resources Protection and Nonstructural Flood Mitigation Experiences" (PROLINE-CE) is co-funded by the European Regional Development Fund, European-Union [Project index number: CE110]. The authors would like to thank the Centro Euro-Mediterraneo per i Cambiamenti Climatici (CMCC, www.cmcc.it) for supplying some climate and land use data.

\section{References}

Aerts, J., Feyen, L., Hochrainer, S., Jongman, B., Hudson, P., Verldkamp, T., 2013. Deliverable 7.3: Risk Scenarios and Analysis, Po River Basin District Case Study - ENHANCE Project.

Ahmad, Z.U., Sakib, S., Gang, D.D. 2016. Nonpoint source pollution. Water Environ. Res. 88, 1594-1619. https://doi.org/10.2175/106143016X14696400495497.

Amadio, M., 2012. Flood Risk Assessment in the Po River Basin Under a Climate Change Scenario. Università Ca' Foscari Venezia.

Arino, O., Perez, J.R., Kalogirou, V., Defourny, P., Achard, F., 2010. Globcover 2009. ESA Living Planet Symp, pp. 1-3.

Autorità di Bacino del Fiume Po, 2015. Piano di Gestione del distretto idrografico del fiume Po.

Aylward, B., Bandyopadhyay, J., Belausteguigotia, J.-C., 2005. Freshwater Ecosystem Services. Ecosyst. Hum. Well-Being Policy Responses vol. 3 pp. 213-256.

Bao, T.Q., 2011. Effect of mangrove forest structures on wave attenuation in coastal Vietnam. Oceanologia 53, 807-818. https://doi.org/10.5697/oc.53-3.807.

Baranzelli, C., Jacobs-Crisioni, C., Batista e Silva, F., Perpiña Castillo, C., Barbosa, A., Arevalo Torres, J., Lavalle, C., 2014. The Reference Scenario in the LUISA Platform - Updated Configuration 2014. vol. 10. Publ. Off. Eur. Union, Luxemb, 85104. https://doi.org/ $10.2788 / 85104$

Barker, T., Mortimer, M., Perrings, C., 2010. Biodiversity, ecosystems and ecosystem services. Econ. Ecosyst. Biodivers. Ecol. Econ. Found, pp. 41-104 https://doi.org/ 10.4324/9781849775489 Chapter 2.

Baruffi, F., Cisotto, A., Cimolino, A., Ferri, M., Monego, M., Norbiato, D., Cappelletto, M., Bisaglia, M., Pretner, A., Galli, A., Scarinci, A., Marsala, V., Panelli, C., Gualdi, S., Bucchignani, E., Torresan, S., Pasini, S., Critto, A., Marcomini, A., 2012. Climate change 
impact assessment on Veneto and Friuli plain groundwater. Part I: an integrated modeling approach for hazard scenario construction. Sci. Total Environ. 440, 154-166. https://doi.org/10.1016/j.scitotenv.2012.07.070.

Bloomfield, J.P., Williams, R.J., Gooddy, D.C., Cape, J.N., Guha, P., 2006. Impacts of climate change on the fate and behaviour of pesticides in surface and groundwatera UK perspective. Sci. Total Environ. 369, 163-177. https://doi.org/10.1016/j. scitotenv.2006.05.019.

Bonaldo, D., Benetazzo, A., Sclavo, M., Carniel, S., 2015. Modelling wave-driven sediment transport in a changing climate: a case study for northern Adriatic Sea (Italy). Reg. Environ. Chang. 15, 45-55. https://doi.org/10.1007/s10113-014-0619-7.

Brilli, L., Moriondo, M., Ferrise, R., Dibari, C., Bindi, M., 2014. Climate change and Mediterranean crops: 2003 and 2012, two possible examples of the near future. Agrochimica 58, 20-33.

Bucchignani, E., Montesarchio, M., Zollo, A.L., Mercogliano, P., 2016. High-resolution climate simulations with COSMO-CLM over Italy: performance evaluation and climate projections for the 21st century. Int. J. Climatol. 36, 735-756. https://oi.org/ $10.1002 /$ joc. 4379 .

Camorani, G., Castellarin, A., Brath, A., 2005. Effects of land-use changes on the hydrologic response of reclamation systems. Phys. Chem. Earth 30, 561-574. https://doi.org/ 10.1016/j.pce.2005.07.010.

Carpenter, S.R., Stanley, E.H., Vander Zanden, M.J., 2011. State of the world's freshwater ecosystems: physical, chemical, and biological changes. Annu. Rev. Environ. Resour. 36, 75-99. https://doi.org/10.1146/annurev-environ-021810-094524.

Carrera, L., Mysiak, J., Crimi, J., 2013. Drought in Northern Italy: Taken by Surprise, Again.

Carrera, L., Standardi, G., Bosello, F., Mysiak, J., 2015. Assessing direct and indirect economic impacts of a flood event through the integration of spatial and computable general equilibrium modelling. Environ. Model. Softw. 63, 109-122. https://doi.org/ 10.1016/j.envsoft.2014.09.016.

Castaldelli, G., Soana, E., Racchetti, E., Pierobon, E., Mastrocicco, M., Tesini, E., Fano, E.A., Bartoli, M., 2013. Nitrogen budget in a lowland coastal area within the Po River Basin (Northern Italy): multiple evidences of equilibrium between sources and internal sinks. Environ. Manag. 52, 567-580. https://doi.org/10.1007/ s00267-013-0052-6.

Castelletti, A., Pianosi, F., Quach, X., Soncini-Sessa, R., 2012. Assessing water reservoirs management and development in northern Vietnam. Hydrol. Earth Syst. Sci. 16, 189-199. https://doi.org/10.5194/hess-16-189-2012.

Cazzolla Gatti, R., 2016. Freshwater biodiversity: a review of local and global threats. Int. J. Environ. Stud. 73, 887-904. https://doi.org/10.1080/00207233.2016.1204133.

Chaudhry, P., Ruysschaert, G., 2008. Climate change and human development in Viet Nam. Hum. Dev. Rep. 2007/2008.

Ciccarelli, N., von Hardenberg, J., Provenzale, A., Ronchi, C., Vargiu, A., Pelosini, R., 2008. Climate variability in north-western Italy during the second half of the 20th century. Glob. Planet. Chang. 63, 185-195. https://doi.org/10.1016/j. gloplacha.2008.03.006.

Colombani, N., Dinelli, E., Mastrocicco, M., 2016a. Trend of heavy metal release according to forecasted climate change in the Po Delta. Environ. Process. 3, 553-567. https://doi. org/10.1007/s40710-016-0146-2.

Colombani, N., Osti, A., Volta, G., Mastrocicco, M., 2016b. Impact of climate change on salinization of coastal water resources. Water Resour. Manag. 30, 2483-2496. https:// doi.org/10.1007/s11269-016-1292-z.

Coppola, E., Giorgi, F., 2009. An assessment of temperature and precipitation change projections over Italy from recent global and regional climate model simulations. Int. J. Climatol. 30, 11-32. https://doi.org/10.1002/joc.1867.

Coppola, E., Verdecchia, M., Giorgi, F., Colaiuda, V., Tomassetti, B., Lombardi, A., 2014 Changing hydrological conditions in the Po basin under global warming. Sci. Total Environ. 493, 1183-1196. https://doi.org/10.1016/j.scitotenv.2014.03.003.

Corazzari, L., Bianchini, G., Billi, P., Marchina, C., Natali, C., 2015. A preliminary note on carbon and nitrogen elemental and isotopic composition of Po River suspended load. Rend. Lincei 27, 89-93. https://doi.org/10.1007/s12210-015-0460-z.

Cozzi, S., Giani, M., 2011. River water and nutrient discharges in the Northern Adriatic Sea: current importance and long term changes. Cont. Shelf Res. 31, 1881-1893. https://doi.org/10.1016/j.csr.2011.08.010.

Däll, P., Zhang, J., 2010. Impact of climate change on freshwater ecosystems: a global-scale analysis of ecologically relevant river flow alterations. Hydrol. Earth Syst. Sci. 14, 783-799. https://doi.org/10.5194/hess-14-783-2010.

Dang, T.H., Coynel, A., Orange, D., Blanc, G., Etcheber, H., Le, L.A., 2010. Long-term monitoring (1960-2008) of the river-sediment transport in the Red River Watershed (Vietnam): temporal variability and dam-reservoir impact. Sci. Total Environ. 408, 4654-4664. https://doi.org/10.1016/j.scitotenv.2010.07.007.

Domeneghetti, A., Carisi, F., Castellarin, A., Brath, A., 2015. Evolution of flood risk over large areas: quantitative assessment for the Po river. J. Hydrol. 527, 809-823. https://doi.org/10.1016/j.jhydrol.2015.05.043.

Duc, N.H., Umeyama, M., 2011. Saline intrusion due to the accelerative sea level in the Red River system in Vietnam. World Environmental and Water Resources Congress 2011: Bearing Knowledge for Sustainability, pp. 4413-4422 https://doi.org/10.1061/41173 (414) 459 .

Duc, D.M., Nhuan, M.T., Van Ngoi, C., 2012. An analysis of coastal erosion in the tropical rapid accretion delta of the Red River, Vietnam. J. Asian Earth Sci. 43, 98-109. https://doi.org/10.1016/j.jseaes.2011.08.014.

Duong, P.C., Nauditt, A., Nam, H., Phong, N.T., 2016. Assessment of climate change impact on river flow regimes in the Red River Delta, Vietnam - a case study of the Nhue-Day River Basin. J. Nat. Resour. Dev. 06, 81-91. https://doi.org/ $10.5027 /$ jnrd.v6i0.09.

Egoh, B., Drakou, E.G., Maes, J., Willemen, L., 2012. Indicators for mapping ecosystem services: a review. JRC Scientific and Policy Reports https://doi.org/10.13140/ 2.1.3420.2565.
Ekka, A., Pandit, A., 2012. Willingness to pay for restoration of natural ecosystem: a study of Sundarban Mangroves by contingent valuation approach. Indian J. Agric. Econ. 67, 323-333.

European Commission, 2011. The EU Biodiversity Strategy to 2020. https://doi.org/ $10.2779 / 39229$

Facca, C., Bilaničovà, D., Pojana, G., Sfriso, A., Marcomini, A., 2014. Harmful algae records in Venice lagoon and in Po River Delta (northern Adriatic Sea, Italy). Sci. World J. https://doi.org/10.1155/2014/806032.

Gao, J., Dai, Z., Mei, X., Ge, Z., Wei, W., Xie, H., Li, S., 2015. Interference of natural and anthropogenic forcings on variations in continental freshwater discharge from the Red River (Vietnam) to sea. Quat. Int. 380, 133-142. https://doi.org/10.1016/j. quaint.2015.01.007.

Giang, P.Q., Toshiki, K., Kunikane, S., Sakata, M., 2013. Climate change challenges transboundary water resources management: drawing from the case of Vietnam. 3rd Int. Conf. Chem. Biol. Environ. Sci, pp. 48-52.

Giani, M., Djakovac, T., Degobbis, D., Cozzi, S., Solidoro, C., Umani, S.F., 2012. Recent changes in the marine ecosystems of the northern Adriatic Sea. Estuar. Coast. Shelf Sci. 115, 1-13. https://doi.org/10.1016/j.ecss.2012.08.023.

Giuliani, M., Anghileri, D., Castelletti, A., Vu, P.N., 2015. Report D7.2 of IMRR Project Estimating the Effects of Climate Change and Designing Adaptation Policies.

Giuliani, M., Anghileri, D., Castelletti, A., Vu, P.N., Soncini-Sessa, R., 2016. Large storage operations under climate change: expanding uncertainties and evolving tradeoffs. Environ. Res. Lett. 11, 035009. https://doi.org/10.1088/1748-9326/11/3/035009.

Grellier, S., Janeau, J.L., Dang Hoai, N., Nguyen Thi Kim, C., Le Thi Phuong, Q., Pham Thi Thu, T., Tran-Thi, N.T., Marchand, C., 2017. Changes in soil characteristics and C dynamics after mangrove clearing (Vietnam). Sci. Total Environ. 593, 654-663. https://oi.org/ 10.1016/j.scitotenv.2017.03.204.

Ha, Q.D., Pintor, L.L., 2014. Climate change adaptation of coastal communities in the Red River. J. Nat. Stud. 13, 1-8.

Ha, T.H., Marchand, C., Aimé, J., Dang, H.N., Phan, N.H., Nguyen, X.T., Nguyen, T.K.C., 2018 Belowground carbon sequestration in a mature planted mangroves (Northern Viet Nam). For. Ecol. Manag. 407, 191-199. https://doi.org/10.1016/j.foreco.2017.06.057.

Haddeland, I., Heinke, J., Biemans, H., Eisner, S., Flörke, M., Hanasaki, N., Konzmann, M. Ludwig, F., Masaki, Y., Schewe, J., Stacke, T., Tessler, Z.D., Wada, Y., Wisser, D., 2014 Global water resources affected by human interventions and climate change. Proc Natl. Acad. Sci. U. S. A. 111, 3251-3256. https://doi.org/10.1073/pnas.1222475110.

Hijmans, R.J., Cameron, S.E., Parra, J.L., Jones, P.G., Jarvis, A., 2005. Very high resolution interpolated climate surfaces for global land areas. Int. J. Climatol. 25, 1965-1978. https://doi.org/10.1002/joc.1276.

Hoang, H.T.T., Duong, T.T., Nguyen, K.T., Le, Q.T.P., Luu, M.T.N., Trinh, D.A., Le, A.H., Ho, C.T Dang, K.D., Némery, J., Orange, D., Klein, J., 2018. Impact of anthropogenic activities on water quality and plankton communities in the Day River (Red River Delta, Vietnam). Environ. Monit. Assess. 190. https://doi.org/10.1007/s10661-017-6435-z.

IPCC, 2014. Climate Change 2014 Synthesis Report Summary Chapter for Policymakers. IPCC https://doi.org/10.1017/CBO9781107415324.

Kandziora, M., Burkhard, B., Müller, F., 2013. Interactions of ecosystem properties, ecosystem integrity and ecosystem service indicators - a theoretical matrix exercise. Ecol. Indic. 28, 54-78. https://doi.org/10.1016/j.ecolind.2012.09.006.

Kernan, M., Battarbee, R.W., Moss, B., 2011. Climate Change Impacts on Freshwater Ecosystems. John Wiley \& Sons.

Khoi, D.N., Suetsugi, T., 2014. Impact of climate and land-use changes on hydrological processes and sediment yield-a case study of the Be River catchment, Vietnam. Hydrol Sci. J. 59, 1095-1108. https://doi.org/10.1080/02626667.2013.819433.

Kundzewicz, Z.W., Mata, L.J., Arnell, N.W., Döll, P., Jimenez, B., Oki, T., Sen, Z., Shiklomanov I., 2008. The Implications of Projected Climate Change for Freshwater Resources and Their Management Resources and Their Management 6667. https://doi.org/10.1623/ hysj.53.1.3.

Lanzoni, S., Luchi, R., Bolla Pittaluga, M., 2015. Modeling the morphodynamic equilibrium of an intermediate reach of the Po River (Italy). Adv. Water Resour. 81, 95-102. https://doi.org/10.1016/j.advwatres.2014.11.004.

Le, T.P.Q., Garnier, J., Gilles, B., Sylvain, T., Van Minh, C., 2007. The changing flow regime and sediment load of the Red River, Viet Nam. J. Hydrol. 334, 199-214. https://doi org/10.1016/j.jhydrol.2006.10.020.

Le, T.P.Q., Dao, V.N., Rochelle-Newall, E., Garnier, J., Lu, X.X., Billen, G., Duong, T.T., Ho, C.T., Etcheber, H., Nguyen, T.M.H., Nguyen, T.B.N., Nguyen, B.T., Da Le, N., Pham, Q.L., 2017 Total organic carbon fluxes of the Red River system (Vietnam). Earth Surf. Process. Landf. 42, 1329-1341. https://doi.org/10.1002/esp.4107.

Li, X., Chen, G., Liu, X., Liang, X., Wang, S., Chen, Y., Pei, F., Xu, X., 2017. A new global landuse and land-cover change product at a 1-km resolution for 2010 to 2100 based on human-environment interactions. Ann. Am. Assoc. Geogr. 107, 1040-1059. https:// doi.org/10.1080/24694452.2017.1303357.

Lionello, P., Abrantes, F., Gacic, M., Planton, S., Trigo, R., Ulbrich, U., 2014. The climate of the Mediterranean region: research progress and climate change impacts. Reg. Environ. Chang. 14, 1679-1684. https://doi.org/10.1007/s10113-014-0666-0.

Lu, X.X., Oeurng, C., Le, T.P.Q., Thuy, D.T., 2015. Sediment budget as affected by construction of a sequence of dams in the lower Red River, Viet Nam. Geomorphology 248, 125-133. https://doi.org/10.1016/j.geomorph.2015.06.044.

Luigi, V., Giuseppe, M., Claudio, R., 2015. Emerging and priority contaminants with endocrine active potentials in sediments and fish from the River Po (Italy). Environ. Sci. Pollut. Res. 22, 14050-14066. https://doi.org/10.1007/s11356-015-4388-8.

Luu, T.N.M., Garnier, J., Billen, G., Orange, D., Némery, J., Le, T.P.Q., Tran, H.T., Le, L.A., 2010. Hydrological regime and water budget of the Red River Delta (Northern Vietnam). J. Asian Earth Sci. 37, 219-228. https://doi.org/10.1016/j.jseaes.2009.08.004.

Madsen, H., Lawrence, D., Lang, M., Martinkova, M., Kjeldsen, T.R., 2014. Review of trend analysis and climate change projections of extreme precipitation and floods in Europe. J. Hydrol. 519, 3634-3650. https://doi.org/10.1016/j.jhydrol.2014.11.003. 
Maes, J., Teller, A., Erhard, M., Liquete, C., Braat, L., Berry, P., Egoh, B., Puydarrieux, P. Fiorina, C., Santos, F., 2013. Mapping and Assessment of Ecosystems and Their Services. https://doi.org/10.2779/75203.

Maran, S., Volonterio, M., Gaudard, L., 2014. Climate change impacts on hydropower in an alpine catchment. Environ. Sci. Pol. 43, 15-25. https://doi.org/10.1016/j. envsci.2013.12.001.

Marchina, C., Natali, C., Fazzini, M., Fusetti, M., Tassinari, R., Bianchini, G., 2017. Extremely dry and warm conditions in northern Italy during the year 2015: effects on the Po river water. Rend. Lincei 28, 281-290. https://doi.org/10.1007/s12210-017-0596-0.

Masoero, A., Claps, P., Asselman, N.E.M., Mosselman, E., Di Baldassarre, G., 2013. Reconstruction and analysis of the Po River inundation of 1951. Hydrol. Process. 27. 1341-1348. https://doi.org/10.1002/hyp.9558.

McCoy, N., Chao, B., Gang, D.D., 2015. Nonpoint source pollution. Water Environ. Res. 87, 1576-1594. https://doi.org/10.2175/106143015X14338845156263.

Minister, T.V.P., 2013. Decision No. 795/QD-TTg of May 23, 2013, Approving a Master Plan on Socio-Economic Development in the Red River Delta Through 2020.

Montanari, A., 2012. Hydrology of the Po River: looking for changing patterns in river discharge. Hydrol. Earth Syst. Sci. 16, 3739-3747. https://doi.org/10.5194/hess-16-37392012 .

Mooney, H., Larigauderie, A., Cesario, M., Elmquist, T., Hoegh-Guldberg, O., Lavorel, S., Mace, G.M., Palmer, M., Scholes, R., Yahara, T., 2009. Biodiversity, climate change and ecosystem services. Curr. Opin. Environ. Sustain. 1, 46-54. https://doi.org/ 10.1016/j.cosust.2009.07.006

Moore, M.V., Pace, M.L., Mather, J.R., Murdoch, P.S., Howarth, R.W., Folt, C.L., Chen, C.Y. Hemond, H.F., Flebbe, P.A., Driscoll, C.T., 1997. Potential effects of climate change on freshwater ecosystems of the New England/Mid-Atlantic Region. Hydrol. Process. 11, 925-947. https://doi.org/10.1002/(SICI)1099-1085(19970630)11:8<925::AIDHYP512>3.0.CO;2-X.

Musolino, D., De Carli, A., Massarutto, A, 2017. Evaluation of the socioeconomic impacts of the drought events: the case of the Po River basin. Eur. Countrys. 9, 163-176. https:// doi.org/10.1515/euco-2017-0010.

Neumann, J., Emanuel, K., Ravela, S., Ludwig, L., Verly, C., 2015. Risks of coastal storm surge and the effect of sea level rise in the Red River Delta, Vietnam. Sustainability 7, 6553-6572. https://doi.org/10.3390/su7066553.

Ngo, T.S., Nguyen, D.B., Prasad, S.R., 2015. Effect of land use change on runoff and sediment yield in Da River Basin of Hoa Binh province, Northwest Vietnam. J. Mt. Sci. 12, 1051-1064. https://doi.org/10.1007//s11629-013-29.

Olubode-Awosola, F., 2017. Project Summary Report - Fresh Water Ecosystem Services Project - Phase 1

Pedro-Monzonís, M., Del Longo, M., Solera, A., Pecora, S., Andreu, J., 2016. Water accounting in the Po River basin applied to climate change scenarios. Procedia Eng. 162, 246-253. https://doi.org/10.1016/j.proeng.2016.11.051.

Phuong Nam, V., Van Anh, T., 2010. Assessing the Impact of Climate Change on the Inflow to Hoa Binh Reservoir, Vietnam. Politecnico di Milano.

Pieri, L., Ventura, F., Ventura, M., Tagliavini, M., Ponti, M., Pistocchi, R., Albertazzi, S. Vignudelli, M., Pisa, P.R., 2011. Chemical and biological indicators of water quality in three agricultural watersheds of the Po valley, Italy. Ital. J. Agron. 6, 29-38. https://doi.org/10.4081/ija.2011.e36.

Preciso, E., Salemi, E., Billi, P., 2012. Land use changes, torrent control works and sediment mining: effects on channel morphology and sediment flux, case study of the Reno River (Northern Italy). Hydrol. Process. 26, 1134-1148. https://doi.org/10.1002/ hyp. 8202.

Raghavan, S.V., Vu, M.T., Liong, S.Y., 2017. Ensemble climate projections of mean and extreme rainfall over Vietnam. Glob. Planet. Chang. 148, 96-104. https://doi.org/ 10.1016/j.gloplacha.2016.12.003.

Ranzi, R., Le, T.H., Rulli, M.C., 2012. A RUSLE approach to model suspended sediment load in the Lo river (Vietnam): effects of reservoirs and land use changes. J. Hydrol. 422-423, 17-29. https://doi.org/10.1016/j.jhydrol.2011.12.009.

Ravazzani, G., Barbero, S., Salandin, A., Senatore, A., Mancini, M., 2014. An integrated hydrological model for assessing climate change impacts on water resources of the Upper Po River basin. Water Resour. Manag. 29, 1193-1215. https://doi.org/ 10.1007/s11269-014-0868-8

Rizzi, J., Torresan, S., Zabeo, A., Critto, A., Tosoni, A., Tomasin, A., Marcomini, A., 2017. Assessing storm surge risk under future sea-level rise scenarios: a case study in the North Adriatic coast. J. Coast. Conserv. 21, 453-471. https://doi.org/10.1007/ s11852-017-0517-5.

Sample, J.E., Baber, I., Badger, R., 2016. A spatially distributed risk screening tool to asses climate and land use change impacts on water-related ecosystem services. Environ. Model. Softw. 83, 12-26. https://doi.org/10.1016/j.envsoft.2016.05.011.
Schiedek, D., Sundelin, B., Readman, J.W., Macdonald, R.W., 2007. Interactions between climate change and contaminants. Mar. Pollut. Bull. 54, 1845-1856. https://doi.org/ 10.1016/j.marpolbul.2007.09.020.

Simone, B., Ha, T.L., Le, V.S., Micotti, M., Nguyen, T.B.T., Pham, H.V., Quach, T.X., Sessa, R.S., 2013. Report D3.1 Reconnaissance - IMRR Project - Integrated and Sustainable Water Management of Red-Thai Binh River System in a Changing Climate.

Simons, G., Bastiaanssen, W., Ngô, L., Hain, C., Anderson, M., Senay, G., 2016. Integrating global satellite-derived data products as a pre-analysis for hydrological modelling studies: a case study for the Red River basin. Remote Sens. 8, 279. https://doi.org/ $10.3390 /$ rs8040279.

Sorg, A., Bolch, T., Stoffel, M., Solomina, O., Beniston, M., 2012. Climate change impacts on glaciers and runoff in Tien Shan (Central Asia). Nat. Clim. Chang. 2, 725-731. https:// doi.org/10.1038/nclimate1592.

Suen, J.P., 2010. Potential impacts to freshwater ecosystems caused by flow regime alteration under changing climate conditions in Taiwan. Hydrobiologia 649, 115-128. https://doi.org/10.1007/s10750-010-0234-7.

Terrado, M., Acuña, V., Ennaanay, D., Tallis, H., Sabater, S., 2014. Impact of climate extremes on hydrological ecosystem services in a heavily humanized Mediterranean basin. Ecol. Indic. 37, 199-209. https://doi.org/10.1016/j.ecolind.2013.01.016.

Tesi, T., Miserocchi, S., Acri, F., Langone, L., Boldrin, A., Hatten, J.A., Albertazzi, S., 2013. Flood-driven transport of sediment, particulate organic matter, and nutrients from the Po River watershed to the Mediterranean Sea. J. Hydrol. 498, 144-152. https:// doi.org/10.1016/j.jhydrol.2013.06.001.

Tibaldi, S., Cacciamani, C., Pecora, S., 2010. Il Po nel clima che cambia 24. pp. 21-28.

Tobergte, D.R., Curtis, S., 2013. UNDP support to the implementation of sustainable development goal 6. J. Chem. Inf. Model. 53, 1689-1699. https://doi.org/10.1017/ CB09781107415324.004.

Toreti, A., Fioravanti, G., Perconti, W., Desiato, F., 2009. Annual and seasonal precipitation over Italy from 1961 to 2006. Encycl. Atmos. Sci. 4, 1549-1555. https://doi.org/ $10.1002 /$ joc.

Trenberth, K.E., 2011. Changes in precipitation with climate change. Clim. Res. 47, 123-138. https://doi.org/10.3354/cr00953.

Trinh, L, 2009. The Main Environmental Issues Needed to be Greatly Concerned in Setting up a Master Plan of Socio-Economic Development for the Red River Delta Region.

Ulbrich, U., Xoplaki, E., Dobricic, S., García-Herrera, R., Lionello, P., Adani, M., Baldi, M., Barriopedro, D., Coccimiglio, P., Dalu, G., 2013. Past and current climate changes in the Mediterranean Region. Regional Assessment of Climate Change in the Mediterranean. Springer, pp. 9-51 https://doi.org/10.1007/978-94-007-5781-3_2.

Van Dijk, M., Hilderink, H., Van Rooij, W., Rutten, M., Lan, V.C., Kartikasari, K., Ashton, R., 2012. Land Use, Food Security, and Climate Change in Vietnam.

van Maren, D.S., 2007. Water and sediment dynamics in the Red River mouth and adjacent coastal zone. J. Asian Earth Sci. 29, 508-522. https://doi.org/10.1016/j. jseaes.2006.03.012

Vezzoli, R., Mercogliano, P., Pecora, S., Zollo, A.L., Cacciamani, C., 2015. Hydrological simulation of Po River (North Italy) discharge under climate change scenarios using the RCM COSMO-CLM. Sci. Total Environ. 521, 346-358. https://doi.org/10.1016/j. scitotenv.2015.03.096.

Viet, N.D., Tu, D.T., Phong, N.T., Duong, H.H., 2018. Performance assessment of irrigation schemes and water pollution issues raised in the Red River, Vietnam. 6, 1-8. https://doi.org/10.11648/j.ijepp.20180601.11.

Vinh, V.D., Ouillon, S., Thanh, T.D., Chu, L.V., 2014. Impact of the Hoa Binh dam (Vietnam) on water and sediment budgets in the Red River basin and delta. Hydrol. Earth Syst. Sci. 18, 3987-4005. https://doi.org/10.5194/hess-18-3987-2014.

Weiss, J., 2009. The Economics of Climate Change in Southeast Asia: A Regional Review.

Whitehead, P.G., Wilby, R.L., Battarbee, R.W., Kernan, M., Wade, A.J., 2009. A review of the potential impacts of climate change on surface water quality. Hydrol. Sci. J. 54, 101-123. https://doi.org/10.1623/hysj.54.1.101.

Wolff, S., Schulp, C.J.E., Verburg, P.H., 2015. Mapping ecosystem services demand: a review of current research and future perspectives. Ecol. Indic. 55, 159-171. https:// doi.org/10.1016/j.ecolind.2015.03.016.

Woodward, G., Perkins, D.M., Brown, L.E., 2010. Climate change and freshwater ecosystems: impacts across multiple levels of organization. Philos. Trans. R. Soc. B 365, 2093-2106. https://doi.org/10.1098/rstb.2010.0055.

Wösten, J.H.M., De Willigen, P., Tri, N.H., Lien, T.V., Smith, S.V., 2003. Nutrient dynamics in mangrove areas of the Red River Estuary in Vietnam. Estuar. Coast. Shelf Sci. 57, 65-72. https://doi.org/10.1016/S0272-7714(02)00331-1. 